\title{
THE BEHAVIOR OF
}

ELECTROLYTIC SOLUTIONS

AT ELEVATED TEMPERATURES

AS DERIVED FROM

CONDUCTANCE MEASUREMENTS

JUNE 1961

CONTRACT AT-11-1-GEN-14

BETTIS ATOMIC POWER LABORATORY, PITTSBURGH, PA., OPERATED FOR THE U.S. ATOMIC ENERGY COMMISSION BY WESTINGHOUSE ELECTRIC CORPORATION 


\section{DISCLAIMER}

This report was prepared as an account of work sponsored by an agency of the United States Government. Neither the United States Government nor any agency Thereof, nor any of their employees, makes any warranty, express or implied, or assumes any legal liability or responsibility for the accuracy, completeness, or usefulness of any information, apparatus, product, or process disclosed, or represents that its use would not infringe privately owned rights. Reference herein to any specific commercial product, process, or service by trade name, trademark, manufacturer, or otherwise does not necessarily constitute or imply its endorsement, recommendation, or favoring by the United States Government or any agency thereof. The views and opinions of authors expressed herein do not necessarily state or reflect those of the United States Government or any agency thereof. 


\section{DISCLAIMER}

Portions of this document may be illegible in electronic image products. Images are produced from the best available original document. 


\section{THE BEHAVIOR OF ELECTROLYTIC SOLUTIONS AT ELEVATED TEMPERATURES AS DERIVED FROM CONDUCTANCE MEASUREMENTS}

J. M. Wright, W. T. Lindsay, Jr., and T. R. Druga

June 1961

Contract AT-11-1-GEN-14

Price $\$ .75$

Available from the Office of Technical Services:

Department of Commerce,

Washington 25, D. C.

NOTE

This document is an interim memorandum prepared primarily for internal reference anc does not represent a final expression of the opinion of Westinghouse. When this memorandum is distributed externally, it is with the express understanding that Westinghouse makes no representation as to campleteness, accura: $y$, or usability of information contained therein.

BetTIS ATOMIC POWER LABORATORY, PITTSBURGH, PA., OPERATED FOR THE U.S. ATOMIC ENERGY COMMISSION BY WESTINGHOUSE ELECTRIC CORPORATION 


\section{SPECIAL EXTERNAL DISTRIBUTION}

Manager, Pit.sburgh Naval Rezctors Operations Office, AEC

Direztor, Derelopment Division, PINROO

3

Westinghouse, Plant Apparatus Departmer.t, J. D. Batey

Total

\section{LEGAL NOTICE}

Th s report was prepared as ar acccunt of Government sponsored work. Neither the United states, nor the commission, nor any perion acting on behalf of the Commission:

A. Makes any warranty or representation, expressed or implied, with respect to the accuracy, completeness, or usefulness cf the information contained in this report, or that the use of any information, apparatus, method, or process disclosed in this report may not infringe privately owned rights; or

B. Assumes any liabilities wit respect to the use of, or for damages resulting from the use of any irformation, apparatus, nethod, or process disclosed in this report.

As used in the above, "person acting on behalf of the Commission" includes any employe or contractor $0^{2}$ the Commission, or enploye of such contractor, to the extent that such employe or contractor of. the commission, or employe of such contractor prepares, disseminates, or srovices access to, any information pursuant to his employment or contract with the Comission, er his employment with sich contractor. 
II. REVIEW AND INTERPRETATION OF THE NOYES CONDUCTANCE DATA

A. Empirical Method for Determining Complete Ionization of Uniunivalent Electrolytes

B. Equations Describing the Conductance Behavior of Strong 1-1 Electrolytes

C. Determination of $\Lambda^{\circ}$ and the Dissociation Constant, $\mathrm{K}$, tor Electrolytes Which Associate

D. Use of the Bjerrum Theory to Determine if Ion-Pair Formation Explains the Decrease in Ionization of Electrolyte.s at Elevated Temperatures

III. MEASUREMENT OF THE CONDUCTANCES OF LiOH AND $\mathrm{NH}_{4} \mathrm{OH}$ SOLUTIONS OVER THE TEMPERATURE RANGE OF 100 to $520 \mathrm{~F}$

A. Description of the Apparatus 12

B. Operational Procedure

C. Specific Conductance of the Water i5

D. Equivalent Conductances of $\mathrm{NH}_{4} \mathrm{OH}$ Solutions over the Temperature Range of 100 to $560 \mathrm{~F}$

E. Equivalent Conductances of $\mathrm{LiOH}$ Solutions over the Temperature Range of 100 to $520 \mathrm{~F}$

F. Best Values for the Equivalent Conductances of $\mathrm{NH}_{4} \mathrm{OH}$ and $\mathrm{LiOH}$ at Temperature Intervals of $40 \mathrm{~F}$

G. The Behavior of $\mathrm{LiOH}$ Solutions at Elevated Temperatures

H. Behavior of $\mathrm{NH}_{4} \mathrm{OH}$ Solutions at Elevated Temperatures

IV. THE ION-PRODUCT OF WATER AT ELEVATED TEMPERATURES

V. CHANGE IN THE pH OF $\mathrm{H}_{2} \mathrm{O}, \mathrm{LiOH}, \mathrm{AND} \mathrm{NH}_{4} \mathrm{OH}$ SOLUTIONS WITH TEMPERATURE

VI. SUMMARY AND CONCLUSIONS

APPENDIX I. Data Compiled by Noyes on Various Electrolytes at 
THIS PAGE

\section{WAS INTENTIONALLY LEFT BLANK}


This project was initialed at the Beftis Alomic Power Laboratory to devise methods and lechniques for measuring the conductances of reactor solutions at elevated temperatures and to inferpret the results with electrolytic solution theories. This conductance information leads to a better underslanding of the behavior of reactor solutions at elevated temperatures and permits reasonable speculation to be mode regarding behovior of proposed reactor coolant additives.

\section{THE BEHAVIOR OF ELECTROLYTIC SOLUTIOIS AT ELEVATED TEMPERATURES AS DERIVED FROM CONDUCTANCE MEASUREMENTS}

J. M. Wright, W. T. Lindsay, Jr., and T. R. Druga

\section{INTRODUCTION}

Knowledge of the electrical conductivity of solutions is of fundamental importance in understanding the behavior of electrolytic solutions, and provides the simplest and most direct measure of the ionization of substances upon which their chemical behavior depends. In spite of its importance, only A. A. Noyes and associates (Reference 1) have successfully measured this property with reasonable precision for several substances at elevated temperatures. From their efforts, a nucleus has been made available for building general principles governing the behavior of electrolytes at elevated temperatures.

A Bettis Project was initiated to devise methods and techniques for measuring the conductances of reactor solutions at temperatures to $540 \mathrm{~F}$ (289C) and to interpret the results with electrolytic solution theories. As a first step, the conductance data of Noyes were reviewed and interpreted, and general principles were set forth on the expected behavior of various solutions at reactor temperatures. In addition, the conductances of $\mathrm{LiOH}$ and
$\mathrm{NH}_{4} \mathrm{OH}$ solutions were measured at 100 to $560 \mathrm{~F}$. Tris conductance information leads to an understanding of the behavior of reactor solutions at elevated temperatures and permits recsonable speculation to be made on the behavicr of proposed reactor coolant additives.

\section{REVIEW AND INTERPRETATION OF THE NOYES CONDUCTANCE DATA*}

A. Empirical Method for Determining Complete Ionization of Uni-univalent Electrolytes

Onsager (Reference 2) derived fram theoretical considerations the following limiting equation describing the equivalent conductance of a 1-1 electrolyte:

$$
\Lambda=\Lambda^{\circ}-\left(\alpha * \Lambda^{\circ}+\beta *\right) \quad \sqrt{C}
$$

*Only 1-1 electrolytes will be discussed, since this type of electrolyte is the only kind on which sufficient data are available for application of conductance theories. 
in which

$$
\alpha^{*}=\frac{8.20411 \times 10^{5}}{(\mathrm{DT})^{3 / 2}} ; \beta^{*}=\frac{82.4262}{\eta(\mathrm{DT})^{1 / 2}} ;
$$

$\Lambda$ is the equivalent conductance at the electr concentration $\mathrm{C}$ (equiv/liter); $\Lambda^{\circ}$ is the equivalent conductance at infinite dilution; $\mathrm{D}$ is the dielectric constant of the solvert; and $\eta$ is the absolute viscosity of the solvent.

Shedlovsky [Reference 3 tested the applicability of this equation over various concentration ranges by substituting measured $\Lambda$ values in the equation, computirg the $\Lambda^{\circ}$ values, and noting their constancy. The equation is applicable if the computed $\Lambda^{\circ}$ values remain constant with concentration and is not appicable if the computed $\Lambda^{\circ}$ values deviate from constancy. It ivas found by using the most accurate jate measured at room temperature, that the computec $\Lambda^{\circ}$ values were not constant over any appreciable concentration range. Fowever, observation was made that the computed $\Lambda^{\circ}$ values (designated by $\Lambda_{0}^{\prime}$ ) plotted against the tirst power of the concentrazion, usually gave straight lines up to consertrations of about 0.1 1. On this basis, the correct $\Lambda^{\circ}$ ralue for each elec is the intercept of the $\Lambda_{0}^{\prime}$ versus $C$ line at $C=0$. Thus, Shedlovsky found empirically that completely ionized 1-1 electrolytes obey the equation

$$
\Lambda_{\circ}^{\prime} \equiv \frac{\Lambda+\beta * \sqrt{\mathrm{C}}}{1-\alpha^{*} \sqrt{\mathrm{C}}}=\Lambda^{\circ}+\mathrm{BC}
$$

over a concentration range of 0 to $0.1 \mathrm{~N}$ and temperatures of 18 and $25 \mathrm{C}$. Furthermore, it was observed that the slope, $B$, usually had values greater than, but vithin 15 percent of the Onsager limiting slope, $\left(\alpha^{*} \Lambda^{\circ}+\beta * *\right)$. For those salts generally considered not to be completely ionized (nitrates, chlorates, and iodates), the $B$ values were either much less than tie Cnsager limiting slope or no linear relationship existed between $\Lambda_{0}^{\prime}$ and C. Thus, from conductance data, the Shedlovsky method can be used to determine if a particular uni-univalent electrolyte is completely ionized in solution at room temperature. The method is also useful in determining the limiting conductance, $\Lambda^{\circ}$, for strong electrolytes.

To determine the kinds of curves obtained by the Shedlovsky test for different electrolytes at elevated temperature, $\Lambda_{0}^{\prime}$ versus $\subseteq$ plots were made using the conductance data of Noyes (Reference 1) for $\mathrm{NaCl}, \mathrm{KCl}, \mathrm{HCl}, \mathrm{NaOH}, \mathrm{AgNO}$, and $\mathrm{H}_{3} \mathrm{PO}_{4}$ over the temperature range of $18 \mathrm{C}$ $(64.4 \mathrm{~F})$ to $306 \mathrm{C}(593 \mathrm{~F})$. The first four substances, $\mathrm{NaCl}, \mathrm{KCl}, \mathrm{HCl}$, and $\mathrm{NaOH}$, are strong electrolytes at room temperature, $\mathrm{AgNO}_{3}$ is slightly associated, and $\mathrm{H}_{3} \mathrm{PO}_{4}$ is a weak electrolyte. $\Lambda_{\text {。 }}^{\prime}$ versus $C$ plots for these substances are shown in Figures 1 through 6. Appendix I presents the conductance data developed by Noyes, and Table Ilists the dielectric constants and viscosities of water and the $\alpha^{*}$ and $\beta *$ values at various temperatures. These data in Table I, along with the data of Noyes, are required to compute the $\Lambda_{0}^{\prime}$ values. Values for the dielectric constant of water from 18 to $100 \mathrm{C}$ were computed by the Wyman and Ingall (Reference 4) equation,

$$
\begin{aligned}
& \mathrm{D}=78.54\left[1-4.579 \times 10^{-3}(\mathrm{t}-25)+1.19\right. \\
& \left.\mathrm{x} 10^{-5}(\mathrm{t}-25)^{2}-2.8 \times 10^{-8}(\mathrm{t}-25)^{3}\right]
\end{aligned}
$$

and from 100 through $306 \mathrm{C}$ by the Akerlof and Oshry (Reference 5) equation,

$$
\begin{aligned}
& \mathrm{D}=\frac{5321}{\mathrm{~T}}+233.76-0.9297 \mathrm{~T}+1.417 \\
& \times 10^{-3} \mathrm{~T}^{2}-8.292 \times 10^{-7} \mathrm{~T}^{3}
\end{aligned}
$$

Values for the viscosity of water from 18 through $306 \mathrm{C}$ were interpolated from smooth curves of the viscosity data given by Dorsey (Reference 6). 


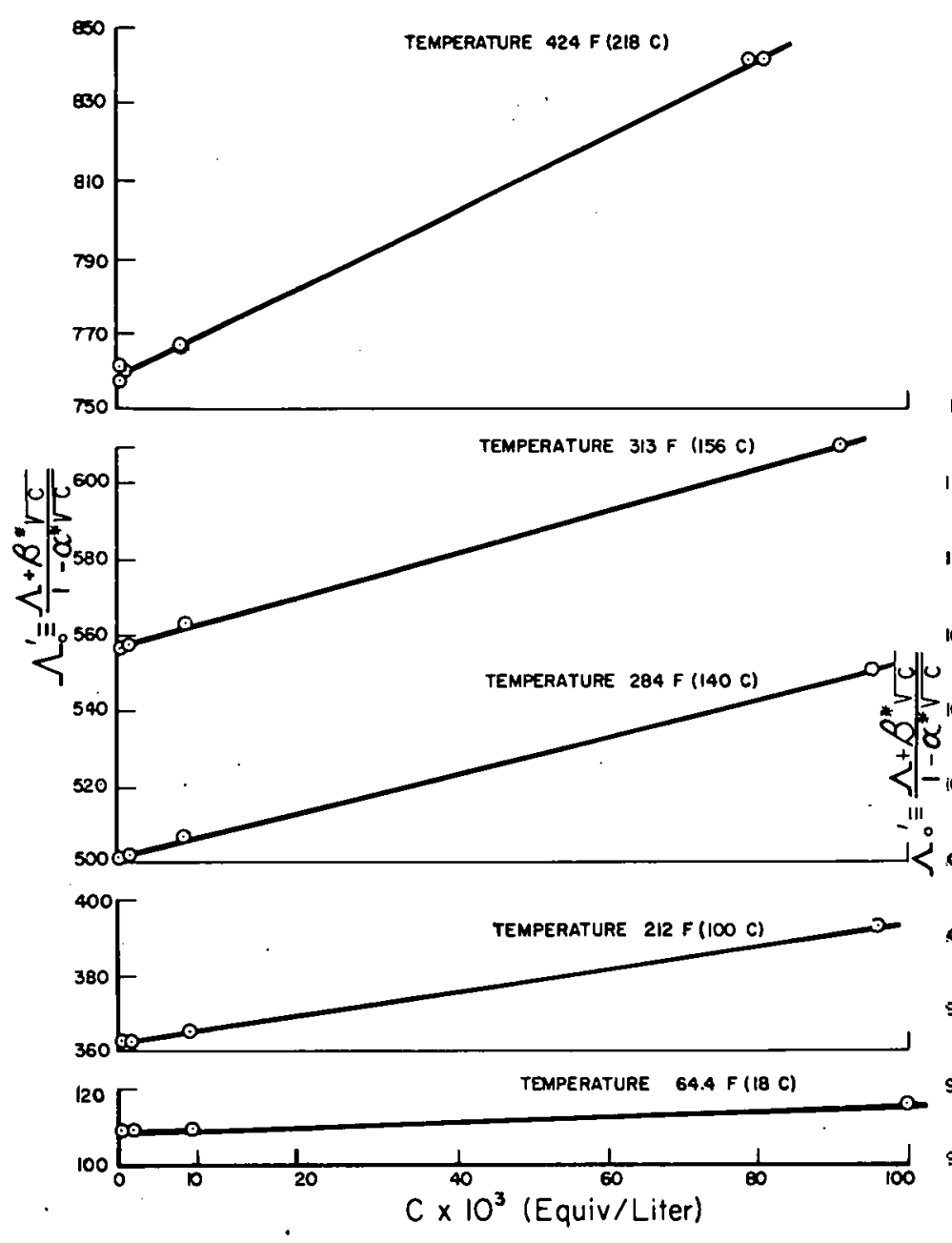

\begin{tabular}{|l|l|l|l|l|}
\hline TEMP & SLOPE & $\begin{array}{c}\text { ONSAGER } \\
\text { SLOPE }\end{array}$ & $\%$ DIFF. & INTERCEPT \\
\hline $18 \mathrm{C}$ & 74.88 & 75.24 & -0.5 & 108.8 \\
\hline $100 \mathrm{C}$ & 322 & 303 & +6 & 362.2 \\
\hline $140 \mathrm{C}$ & 517 & 455 & +12 & $5 C 1.1$ \\
\hline $156 \mathrm{C}$ & 572 & 525 & $\cdot 8$ & 557.1 \\
\hline $218 \mathrm{C}$ & 984 & 847 & +14 & 7.59 .4 \\
\hline & \multicolumn{5}{|l|}{} \\
\hline 281 C EOLATION DCES NOT DESCRIBE DATA \\
\hline 306 CEQUATION COES NOT DESCRIBE DATA \\
\hline
\end{tabular}

$\therefore$

figure 1. Shedlovsky Test on $\mathrm{NaCl}$ Solutions at Various Temperalures 


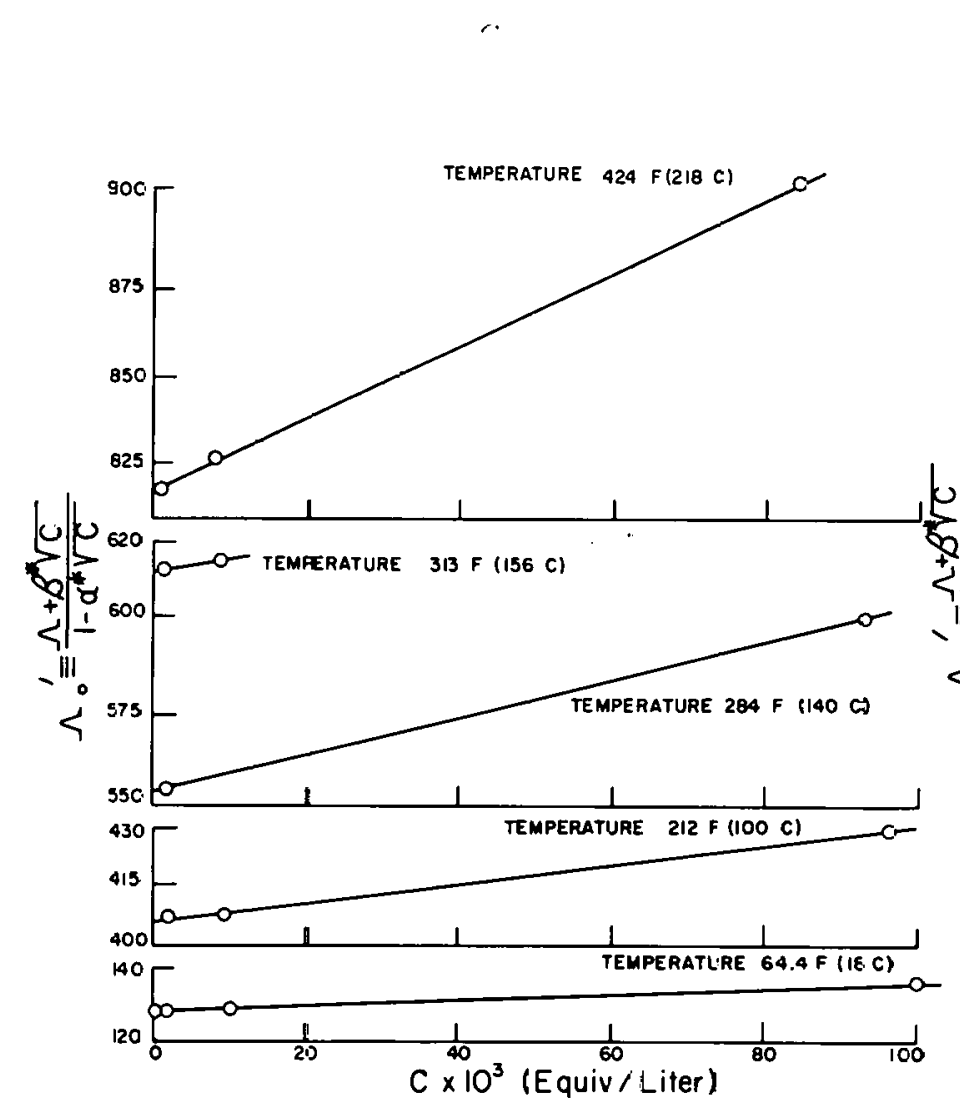

\begin{tabular}{|l|l|l|l|l|}
\hline TEMP & SLOPE & $\begin{array}{c}\text { ONSAGER } \\
\text { SLOPE }\end{array}$ & KOIF! & INTERCEPT N \\
\hline $18 \mathrm{C}$ & 81.34 & 79.97 & +2 & 129.8 \\
\hline $100 \mathrm{C}$ & 320 & 314 & +2 & 406.0 \\
\hline $140 \mathrm{C}$ & 458 & 472 & -3 & 554.5 \\
\hline $156 \mathrm{C}$ & 371 & 543 & -46 & 611.5 \\
\hline $218 \mathrm{C}$ & 967 & 671 & +10 & 817.7 \\
\hline $281 \mathrm{C}$ & 1599 & 1336 & +16 & 898.6 \\
\hline $306 \mathrm{C}$ & EOUATION DOES NOT DESCRIBE DATA \\
\hline
\end{tabular}

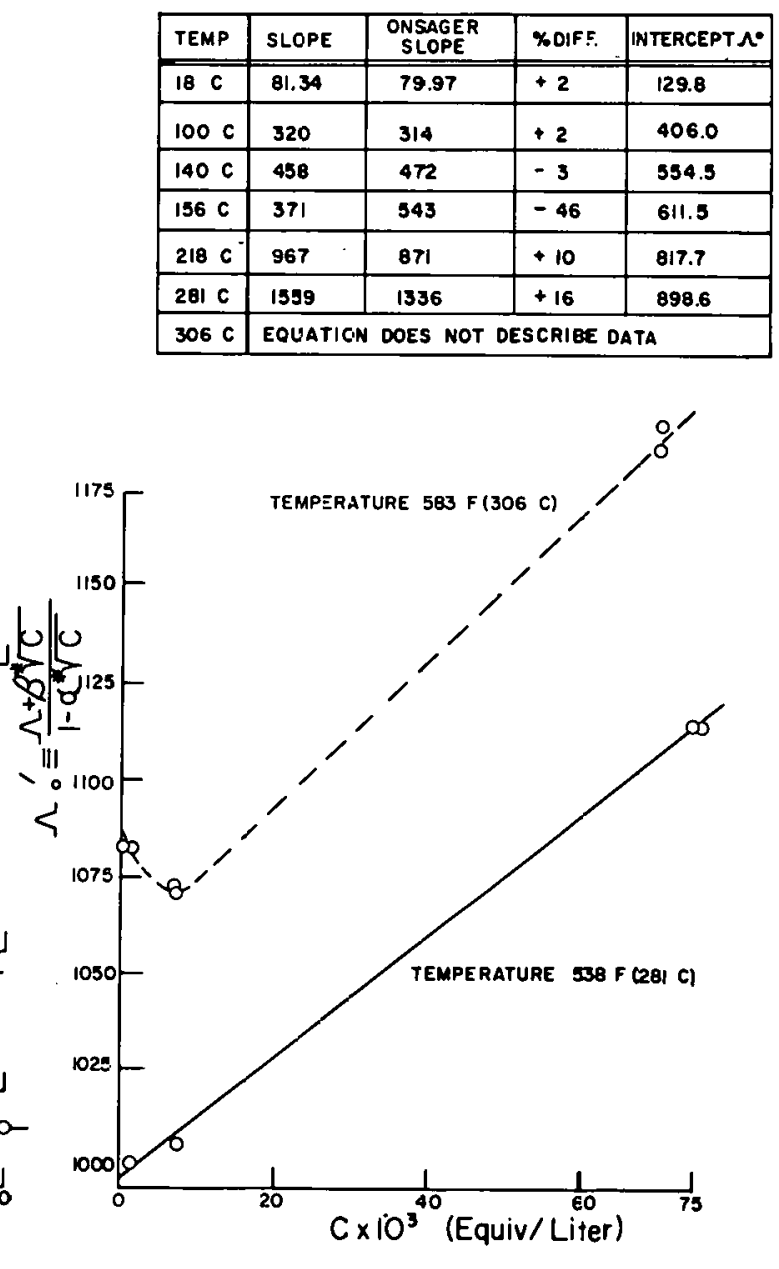

Figure 2. Shedlovsky Test on $\mathrm{KCl}$ Solutions at Various Temperatures 


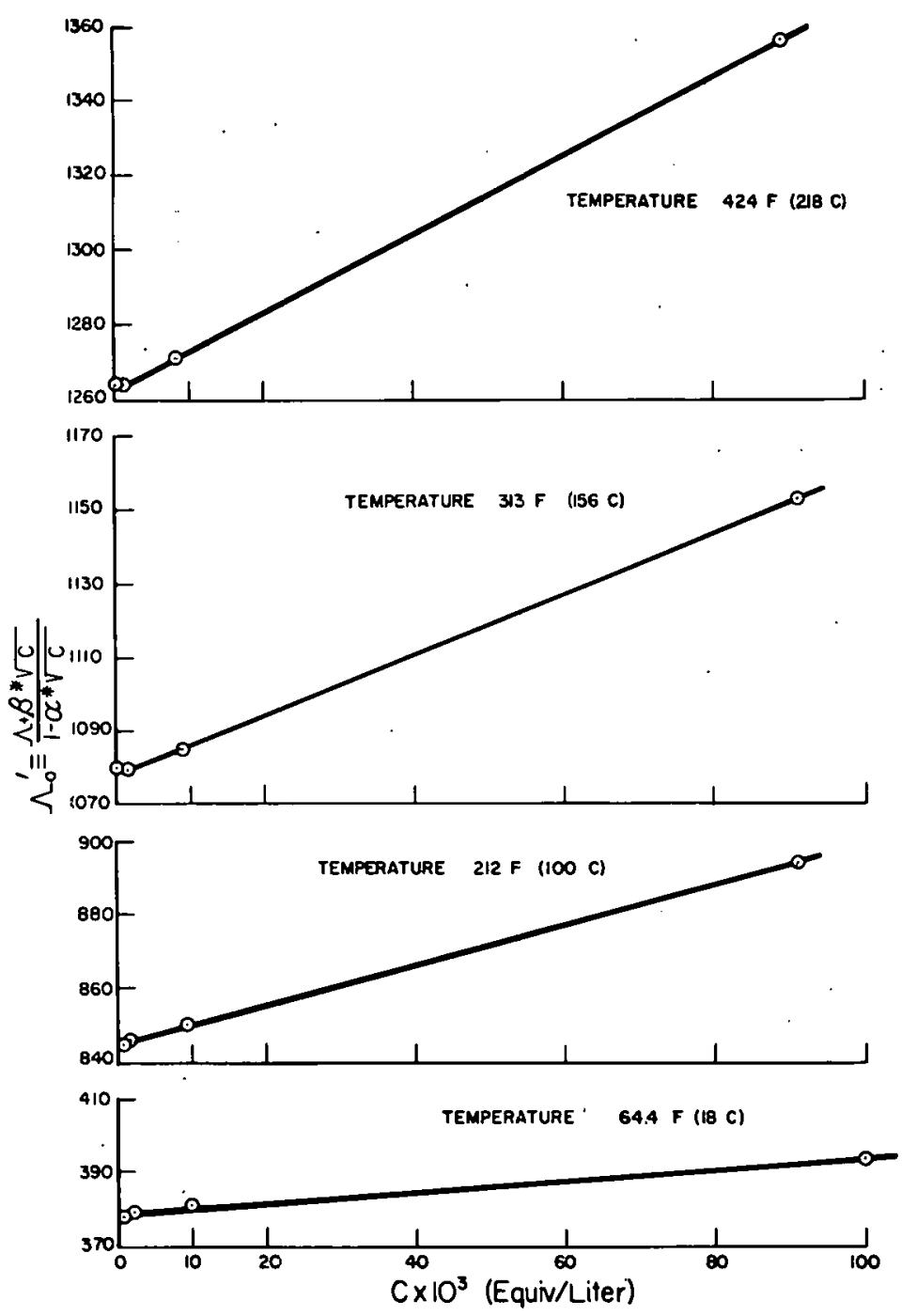

\begin{tabular}{|l|c|c|c|c|}
\hline TEMP & SLOPE & $\begin{array}{c}\text { ONSAGEER } \\
\text { SLOPE }\end{array}$ & $\%$ DIFF & INTERCEPT \\
\hline $18 \mathrm{C}$ & 157 & 136 & $+\mathrm{B}$ & 379.2 \\
\hline $100 \mathrm{C}$ & 520 & 436 & +16 & 845.4 \\
\hline $156 \mathrm{C}$ & 80 & 698 & +14 & 1078.1 \\
\hline $218 \mathrm{C}$ & 1153 & 1061 & +8 & 1263 \\
\hline $260 \mathrm{C}$ & PLOT HAS NEGATIVE SLOPE \\
\hline $306 \mathrm{C}$ & PLOT HAS NEGATIVE SLOPE \\
\hline
\end{tabular}

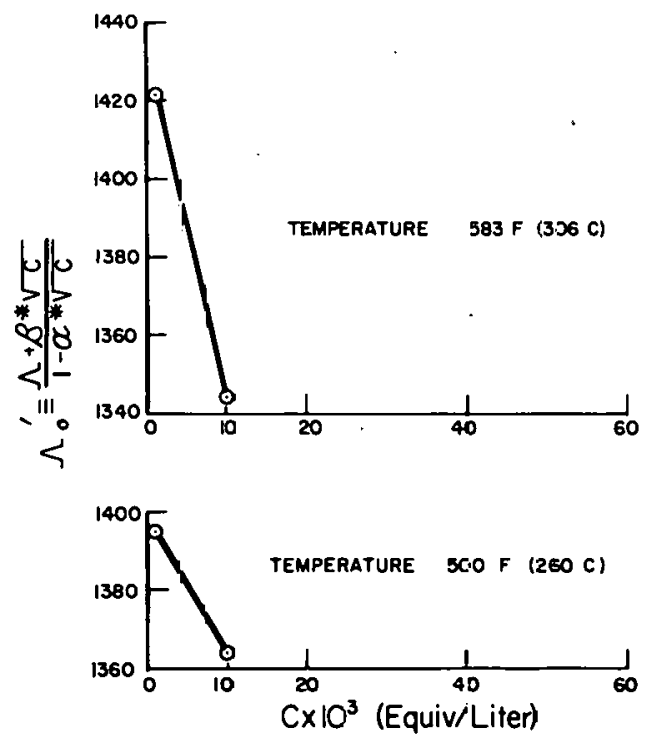

Figure 3. Shedlovsky Test on $\mathrm{HCl}$ Solutions at Various Temperafures 


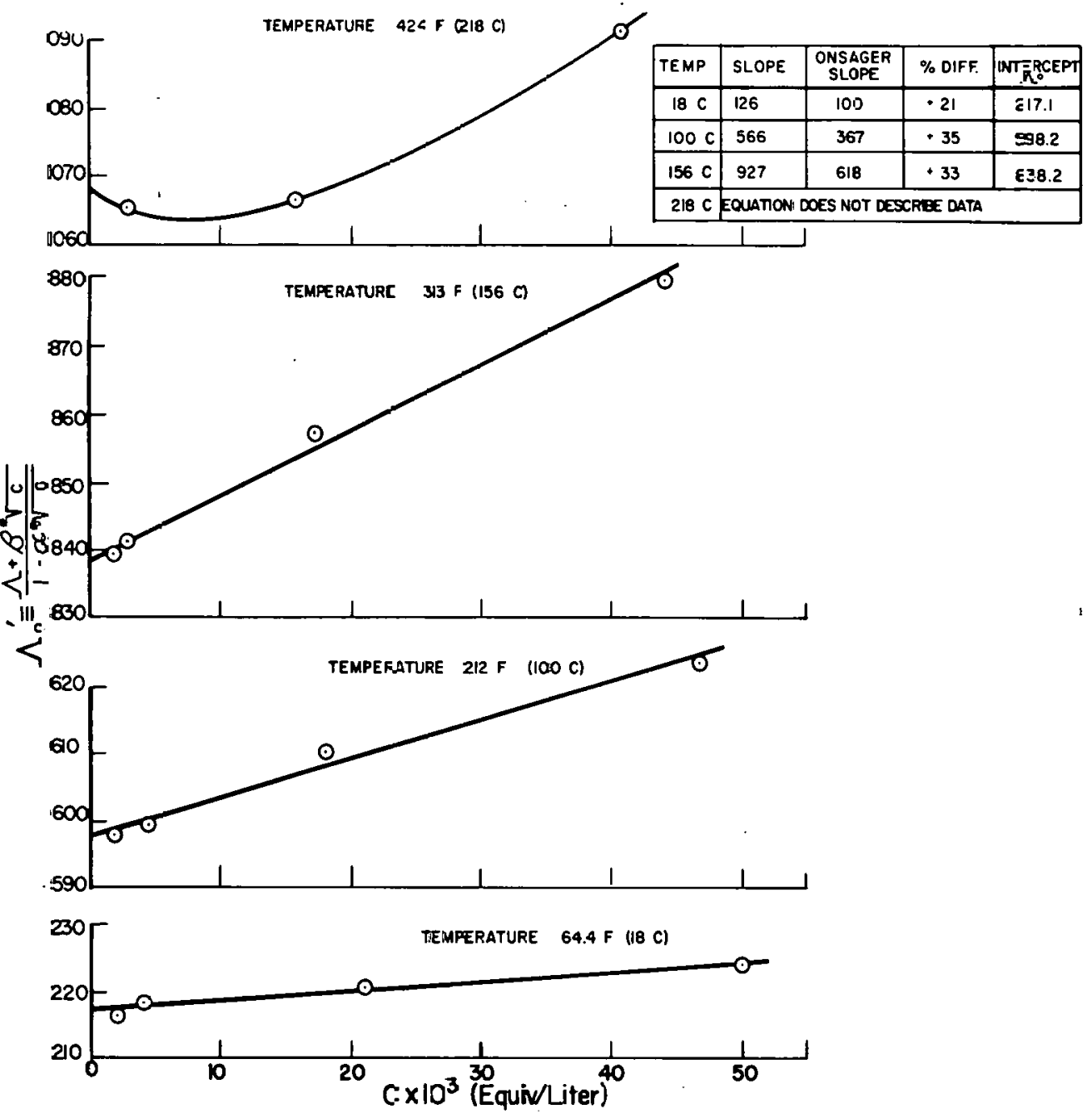

Figare 4. Shedlovsky ies1 or $\mathrm{NaOH}$ Solutions af Various Temperatures 


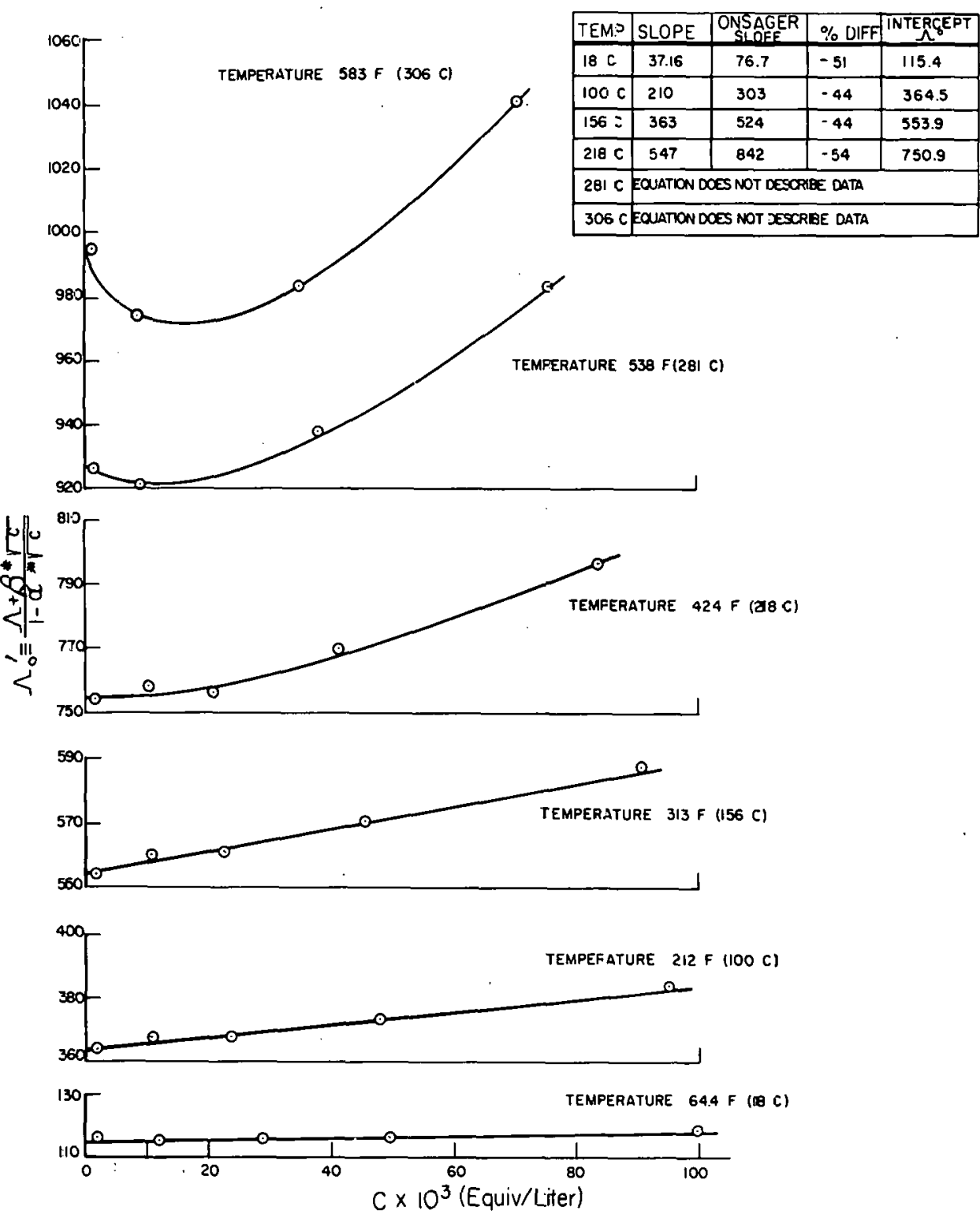

Figure 5. Shedlovsky Test on AgNO, Solutions at Various Temperatures 

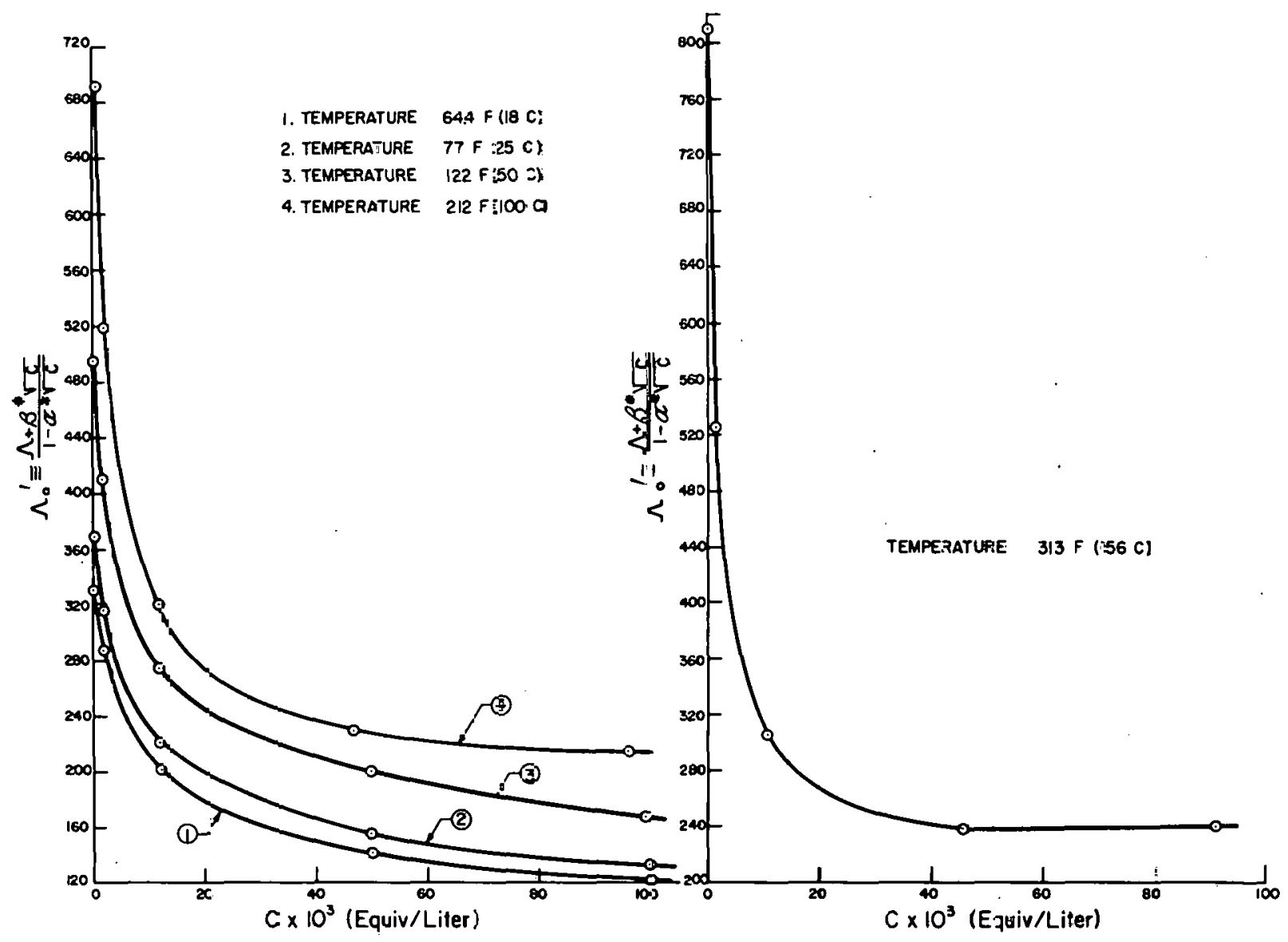

Ficure 6. Shedlovsky Tesl an $\mathrm{H}_{3} \mathrm{PO}_{4}$ Solutions at Various Tempera:ures

TABLE I

PHYSICAL CONSTANTS AT VARIOUS TEMPERATUṬES

\begin{tabular}{cc}
\multicolumn{2}{c}{ Temperature } \\
\hline (C) & (F) \\
\hline 18 & 34.4 \\
25 & 77.0 \\
50 & 122 \\
75 & 137 \\
100 & 212 \\
128 & 252.4 \\
140 & 284 \\
156 & 312.8 \\
218 & 424.4 \\
260 & 500 \\
281 & 537.8 \\
306 & 582.8
\end{tabular}

\begin{tabular}{c}
$\begin{array}{c}\text { Dielectri: } \\
\text { Constant }\end{array}$ \\
\hline 81.10 \\
78.54 \\
70.10 \\
62.62 \\
55.90 \\
48.57 \\
45.93 \\
42.61 \\
31.55 \\
25.19 \\
22.20 \\
18.72
\end{tabular}

\begin{tabular}{|c|c|c|}
\hline $\begin{array}{l}\text { Viscosity } \\
\text { (millipoise) }\end{array}$ & & $\alpha *$ \\
\hline 10.60 & & 0.2261 \\
\hline 8.949 & • & 0.2289 \\
\hline 5.49 & & 0.2406 \\
\hline 3.81 & & 0.2549 \\
\hline 2.839 & & 0.2723 \\
\hline 2.215 & & 0.3016 \\
\hline 2.008 & & 0.3139 \\
\hline 1.793 & & 0.3318 \\
\hline 1.265 & & 0.4254 \\
\hline 1.093 & & 0,5272 \\
\hline 1.008 & & 0.6013 \\
\hline 0.910 & & 0.7269 \\
\hline
\end{tabular}

\begin{tabular}{l}
$\beta *$ \\
\hline 50.60 \\
60.19 \\
99.75 \\
146.5 \\
201.0 \\
266.6 \\
298.0 \\
340.0 \\
523.5 \\
650.8 \\
737.3 \\
870.0
\end{tabular}


Examination of the $\Lambda_{0}^{\prime}$ versus $C$ plots shows the Shedlovsky criterion of a linear relationship was not obeyed by $\mathrm{H}_{3} \mathrm{PO}_{4}$ but it was obeyed by $\mathrm{NaOH}$ up to $156 \mathrm{C}$, by $\mathrm{AgNO}_{3}, \mathrm{NaCl}$, and $\mathrm{HCl}$ up to $218 \mathrm{C}$, and by $\mathrm{KCl}$ up to $281 \mathrm{C}$. Application of the second criterion, a $\mathrm{B}$ value 0 to 15 percent greater than the Onsager slope, was not obeyed by $\mathrm{AgNO}_{3}$ where the slope was between 44 and 54 percent less than the Onsager slope, or $\mathrm{NaOH}$ where the slope exceeded the Onsager slope by 21 to 35 percent.

Thus, if the assumption is made that the Shedlovsky criteria are applicable at any temperature, aqueous solutions of $\mathrm{NaCl}, \mathrm{HCl}$, and $\mathrm{KCl}$ are strong electrolytes up through temperatures of 218,218 , and $281 \mathrm{C}$,respectively. Somewhat above each of these temperatures, the electrolytes begin to associate. Using this same rule, $\mathrm{H}_{3} \mathrm{PO}_{4}$ is a weak electrolyte throughout the measured temperature range. $\mathrm{NaOH}$ is peculiar in that the slope is greater than expected; however, $\mathrm{NaOH}$ is probably a strong electrolyte up to $156 \mathrm{C}$. The data on $\mathrm{AgNO}_{3}$ cannot be properly interpreted because hydrolysis occurs throughout the temperature range.

B. Equations Describing the Conductance Behavior of Strong 1-1 Electrolytes

Many equations have been used to describe the conductance behavior of strong 1-1 electrolytes at room temperature (Reference 7), a few of which were considered in seeking to describe the conductance behavior of electrolytes at elevated temperatures.

The Onsager limiting equation does not describe the conductance of electrolytes over any appreciable concentration range. However, the Shedlovsky linear relationship, Equation (2), has been shown to describe adequately the conductance behavior of $\mathrm{NaCl}, \mathrm{KCl}, \mathrm{NaOH}$, and $\mathrm{HCl}$ to temperatures above $200 \mathrm{C}$ and concentrations up to 0.1. N. Equation (2) can be rewritten as:

$$
\Lambda=\Lambda^{\circ}-\left(\alpha^{*} \Lambda^{\circ}+\beta *\right) \sqrt{\mathrm{C}}+\mathrm{BC}-\alpha^{*} \mathrm{BC}^{3 / 2}
$$

In this form, it is seen to be merely an extension of the Onsager Equation (1) with the added terms, $\mathrm{BC}-\alpha * \mathrm{BC}^{3 / 2}$. This equation has the disadvantage of containing the empirical parameter $B$.

Shedlovsky (Reference 8) proposec another empirical modification of the Onsager equation which quite accurately represents room-temperature conductances of strong electrolytes up to concentrations of about $0.01 \mathrm{~N}$. This equation is:

$$
\Lambda=\Lambda^{\circ}-\frac{\Lambda}{\Lambda^{\circ}}\left(\alpha^{*} \Lambda^{\circ}+\beta^{*}\right) \quad \sqrt{\mathrm{C}},
$$

which may be reazranged as the series,

$$
\begin{aligned}
\Lambda= & \Lambda^{\circ}-\left(\alpha^{*} \Lambda^{0}+\beta^{*}\right) \sqrt{\mathrm{C}}+\frac{\left(\alpha^{*} \Lambda^{\circ}+\beta^{*}\right)^{2} \mathrm{C}}{\Lambda^{\circ}} \\
& -\frac{\left(\alpha^{*} \Lambda^{\circ}+\beta^{*}\right) \mathrm{C}^{3 / 2}}{\left(\Lambda^{0}\right)^{2}}
\end{aligned}
$$

This equation contains only one undetermined parameter and is readily applied to the calculations required later in Section $\Pi-C$.

The recently developed Fuoss-Onsager equations (Reference 17) are derived entirely from theoretical grouncs and contair an ion-size parameter in add:tion to $\Lambda^{\circ}$. It has been shown that these equations accurately represent the conductance data for sirong electrolytes. However, the complex calculations required to apply the Fuoss-Onsager equations to the Noyes results have not been carried out, since a high degree of precision is required of the data to determine accurately the ion-size parameter.

To determine if Equation (6) describes the conductance behavior of electrolytes at elevated temperatures, the Noyes conductance data for $\mathrm{NaCl}$, $\mathrm{KCl}, \mathrm{HCl}, \mathrm{NaOH}, \mathrm{AgNO}_{3}$, and $\mathrm{H}_{3} \mathrm{PO}_{4}$ were substituted into Equation (6); the $\Lambda^{\circ}$ values were computed and their constancy noted. The results cf these calculations show that Equation (6) accurately represents the data for $\mathrm{NaCl}, \mathrm{KCl}, \mathrm{HCl}$, 
and $\mathrm{NaOH}$ to within about 0.1 percent foz concentrations up to $0.01 \mathrm{~N}$ (and to about 0.5 percent up to $0.1 \mathrm{~N}$ at temperatures which show the Shedlovsky linear relationsh.ip between $\Lambda_{0}^{\prime}$ and C. At temperatures where the $\Lambda_{0}^{\prime}$ versus $C$ plots are not linear, the computed $\Lambda^{\circ}$ values are not constant, but decrease with increasing concentration. Therefore, the equation is not applicable at these temperatures.

Equation (6) describes the $\mathrm{AgNO}_{3}$ data to within about 0.1 percent up to $156 \mathrm{C}$. The equation does not describe the data for $\mathrm{H}_{3} \mathrm{PO}_{4}$ at any of the measured temperatures.

Thus, if the Shedlovsk $r$ criteria for strong electrolytes is used, then Equation (6) will adequately describe the conductance behavior of these types of concentrations up to $0: 01 \mathrm{~N}$.

C. Determination of $\Lambda^{\circ}$ and the Dissociation Constant, $K$, for Electrolytes Which Associate

The usual method (References 8 and 9 ) of determining $\Lambda^{\circ}$ and $K$ values for associated electrolytes is:

1) Define the degree of dissociation, $a$ as:

$$
\alpha=\frac{\Lambda}{\Lambda}
$$

in which $A$ is the measured equivalent conductance $::-$ the eleztrolyte at the coucentration $C$, anc $\Lambda_{e}$ is the equivalent conductance that the electrolyte would have if anly: $\alpha \mathrm{C}$ equiv/liter of the completely dissociated electrolyte were in solution.

2) Substitute into Equation (8) an expression for $\Lambda \mathrm{e}$ which describes the conductance behavior of a completely dissociated electrolyte. Thus, $\Lambda$ in Equation (6) is $\Lambda_{\mathrm{e}}$ in Equation (8):

$$
\Lambda=\Lambda_{e}=\frac{\left(\Lambda^{\circ}\right)^{2}}{\left.\Lambda^{\circ}+i \alpha^{*} \Lambda^{\circ}+\beta^{*}\right) \sqrt{\alpha C}} .
$$

Substituting this expression of $\Lambda_{e}$ into Equation (8) and solving for $\alpha$ gives

$\alpha=\frac{\Lambda}{\Lambda^{\circ}}\left[\frac{z}{2}+\sqrt{1+\left(\frac{z}{2}\right)^{2}}\right]^{2} \equiv \frac{\Lambda}{\Lambda^{\circ}} \mathrm{s}(\mathrm{z}) \quad(101$ in which

$$
s(z)=1+z+\frac{z^{2}}{2}+\frac{z^{3}}{8}-\ldots
$$

and

$$
\mathrm{z}=\frac{\left(\alpha^{*} \Lambda^{\circ}+\beta^{*}\right)}{\left(\Lambda^{\circ}\right)^{3 / 2}} \frac{\sqrt{\Lambda \mathrm{C}}}{}
$$

3) Combine the definition of a dissociation constant,

$$
\mathrm{K}=\frac{\alpha^{2} \gamma_{ \pm}{ }^{2} \mathrm{C}}{(1-\alpha)},
$$

with Equation (10), giving

$$
\Lambda \mathrm{s}(\mathrm{z})=\Lambda^{\circ}-\alpha^{2} \mathrm{C} \gamma=^{2}\left(\Lambda^{\circ} / \mathrm{K}\right) .
$$

The mean molar activity coefficient values, $\gamma \pm$, are calculated from the Debye-Huckel limiting law (Reference 10):

$$
\log \gamma \pm=\frac{-1.82 \_2 \times 10^{6} \sqrt{a C}}{(\mathrm{DT})^{3 / 2}}
$$

4) Assume a value for $\Lambda^{\circ}$ in Equation (14) and determine $\Lambda \mathrm{S}(\mathrm{Z})$ and $\alpha^{2} \mathrm{C} \gamma \doteq^{2}$. यsing conductance data at vari.jus concentrations. Plot the $\Lambda \mathrm{S}(\mathrm{Z})$ values versus the $\alpha^{2} \mathrm{C} y \pm{ }^{2}$ values. If the correct $\Lambda^{\circ}$ value was chosen, the intercept at $\mathrm{C}=0$ is $\Lambda^{\circ}$ and the slope is $-\frac{\Lambda^{\circ}}{K_{0}}$. This trial and exror process is repeated until the assumed $\Lambda^{\circ}$ and the $\Lambda^{\circ}$ at $\mathrm{C}=0$ coincide.

This procedure was used to calculate $\Lambda^{\circ}$ and $\mathrm{K}$ values for $\mathrm{NaCl}, \mathrm{KCl}, \mathrm{HCl}, \mathrm{NaOH}, \mathrm{AgNO}_{3}$, and $\mathrm{H}_{3} \mathrm{PO}_{4}$ at those temperatures where the Shedlovsky test indicated the electrolytes were associating. Table II lists the values obtained. 
TABLE II

EQUIVALENT CONDUCTANCES AT INFINITE DILUTION AND DISSOCIATION CONSTANTS FOR SEVERAL ELECTROLYTES AT ELEVATED TEMPERATURES

\begin{tabular}{lc} 
Electrolyte & Temperature (C) \\
\cline { 2 - 2 } $\mathrm{NaCl}$ & 281 \\
& 306 \\
$\mathrm{KCl}$ & 281 \\
& 306 \\
$\mathrm{HCl}$ & 260 \\
& 306 \\
$\mathrm{NaOH}$ & 218 \\
$\mathrm{AgNO}_{3}$ & 218 \\
& 281 \\
$\mathrm{H}_{3} \mathrm{PO}_{4}$ & $3-6$ \\
& 18 \\
& 25 \\
& 50 \\
& 75 \\
& 100 \\
& 125 \\
& 156
\end{tabular}

\begin{tabular}{r}
\multicolumn{1}{c}{$\Lambda^{\circ}$} \\
952 \\
1042 \\
1000 \\
1086 \\
1409 \\
1470 \\
1068 \\
754 \\
931 \\
1007 \\
341 \\
379 \\
513 \\
634 \\
741 \\
846 \\
934
\end{tabular}

\begin{tabular}{l}
\multicolumn{1}{c}{$\mathrm{K}$} \\
\hline 0.22 \\
0.093 \\
0.49 \\
0.12 \\
0.12 \\
0.035 \\
0.55 \\
0.92 \\
0.15 \\
0.069 \\
$8.19 \times 10^{-3}$ \\
$7.63 \times 10^{-3}$ \\
$5.53 \times 10^{-3}$ \\
$3.92 \times 10^{-3}$ \\
$2.69 \times 10^{-3}$ \\
$1.74 \times 10^{-3}$ \\
$1.10 \times 10^{-3}$
\end{tabular}

D. Use of the Bjerrum Theory to Determine if Ion-Pair Formation Explains the Decrease in Ionization of Electrolytes at Elevated Temperatures

Table II shows the ionization of all electrolytes decreases with increasing temperature. To determine if this decrease could be caused by ion-pair formation, recourse was had to the Bjerrum (Reference 11). While this theory has recently been superseded by more elegant variations which do not require certain of the arbitrary assumptions which are necessary in the Bjerrum treatment (Reference 17), it has been used extensively in the past and is still used to explain the low-conductance behavior of strong electrolytes in media of lowdielectric constant (such as water-alcohol mixtures). In such media, the conductance of a strong electrolyte decreases as the dielectric constant of the solvent decreases. Since the dielectric constant for water decreases as temperature increases, the decrease in ionization constant for the electrolytes shown in Table II could be produced by ion-pair formation as opposed to covalent bond formation. Bjerrum assumed an electrolytic solution composed of rigid, nonpolarizable spherical ions in a medium of a fixed macroscopic dielectric constant. With this model, Bjerrum calculated the probability of finding two oppositely charged ions a distance, $r$, from each other and noted that the probability possessed a minimum at a distance, $q$. Then it was assumed that ion-pair formation took place if two oppositely charged ions were closer to each other than the distance $q$ and that jon-pair formation did not take place if the ions were farther from each other than the distance q. Bjerrum derived relationships between the constant for disso:iation of an ion-pair, $K$, the dielectric constant of the medium $\mathrm{D}$ and the temperature of the soluticn $\mathrm{T}$ and the mean distance approach a, between the centers of the two ions forming the pair.

These relationships are:

$$
\begin{gathered}
1 / K=\frac{4 \pi N}{1000}\left(\frac{\left|z_{+} z_{-}\right| \epsilon^{2}}{D k T}\right)^{3} Q(b), \\
Q(b)=\int_{2}^{b} e^{Y} Y^{-4} d Y,
\end{gathered}
$$

and

$$
b=\frac{\left|z_{+} z_{-}\right| \varepsilon^{2}}{a D k T} .
$$


These equations were applied to the $K$ values shown in Table II to determine how the zalculated mean distance of approach, a, varied with temperature and dielectric constant. Values for $K$ and DT were substituted into Equation (16; and $Q(b)$ determined. The value of $b$ was determined from a plot of $Q(B)$ versus $b$. The mean distarce of approach, a, was determined using Equatior (18). Table III shows the variation of a with temperature. Also included in this table are the dis:ances, $q$, at which the probability function possesses a minimum and ionic radii values obtained from X-ray diffraction datc.

According to the Bjerrum theory, ion-pair formation takes place when the mean distance of zlosest approach for the ions lies between the qralues and the sum of the ionic racii. This condition is satisfied by $\mathrm{NaCl}, \mathrm{KCl}, \mathrm{NaOH}$, and perhaps $\exists \mathrm{Cl}$ at the higher temperatures. Therefore, these el $\epsilon$ ctrolytes are considered to show: ion-pair formation. However, the Bjerrum theory is not applicatle to Ag-NO ${ }_{3}$ and $\mathrm{H}_{3} \mathrm{PO}_{4}$ solutions since their a values are less than the sum of the ionic radi iexcept for $\mathrm{AgNO}_{3}$ at $218 \mathrm{C}$ ). This indicates a force is operative which is different than the coulomb attractive force used in the Bjerrum derivation. Presumably, $\mathrm{H}_{3} \mathrm{PO}_{3}$ does not form ion-pairs but associates by covalent-jand formation. Extensive hydrolysis must also be considered to effect the behavior of $\mathrm{AgNO}_{3}$ solutions.

\section{MEASUREMENT O THE CONDUCTANCES OF LiOH AND $\mathrm{NH}_{4} \mathrm{CH}$ SOLUTIONS OVER THE TEMPERATURE RANGE OF 100 TO $520 \mathrm{~F}$.}

\section{A. Description of the Apparatus}

Figure 7 shows the arrangement of the apparatus. The solution was pumped from the 50-liter, polyethylene bottle source tank successively through a mixed-bed, ion-exchange resin*; a lowtemperature, high-pressure conductivity cell; a

\footnotetext{
*The mixed bed resin was of the same form as the solution which was passed through it. For the water runs, as-received $\mathrm{H}-\mathrm{OH}$, form mixed-bed resin was used. For the $\mathrm{LiOH}$ or $\mathrm{NH}_{4} \mathrm{OH}$ runs, the $\mathrm{H}-\mathrm{OH}$ form resin was converted to the $\mathrm{Li}^{+}$ $\mathrm{OH}^{-}$or $\mathrm{NH}_{4}+\mathrm{OH}^{-}$form by passing strong solutions of these bases trrough the resin column. Each column was washed with 30 to 40 liters of demineralized water before being used in order to remove any soluble amines which might be present.
}

TABLE III

CHANGE IN a VALUES; q VALUES AND THE DIELECTRIC CONSTANT OF WATER WITH TEMPERATURE

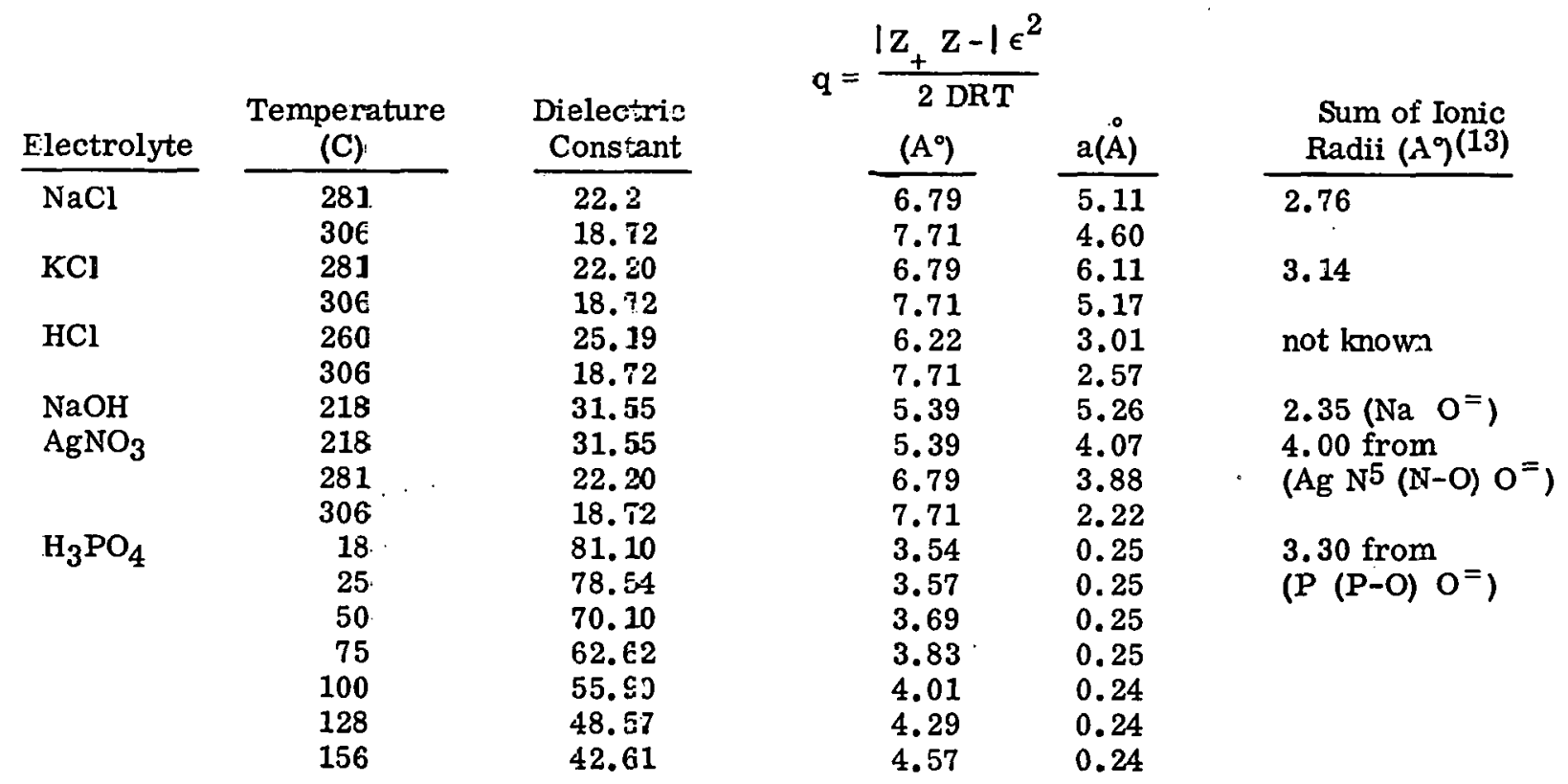




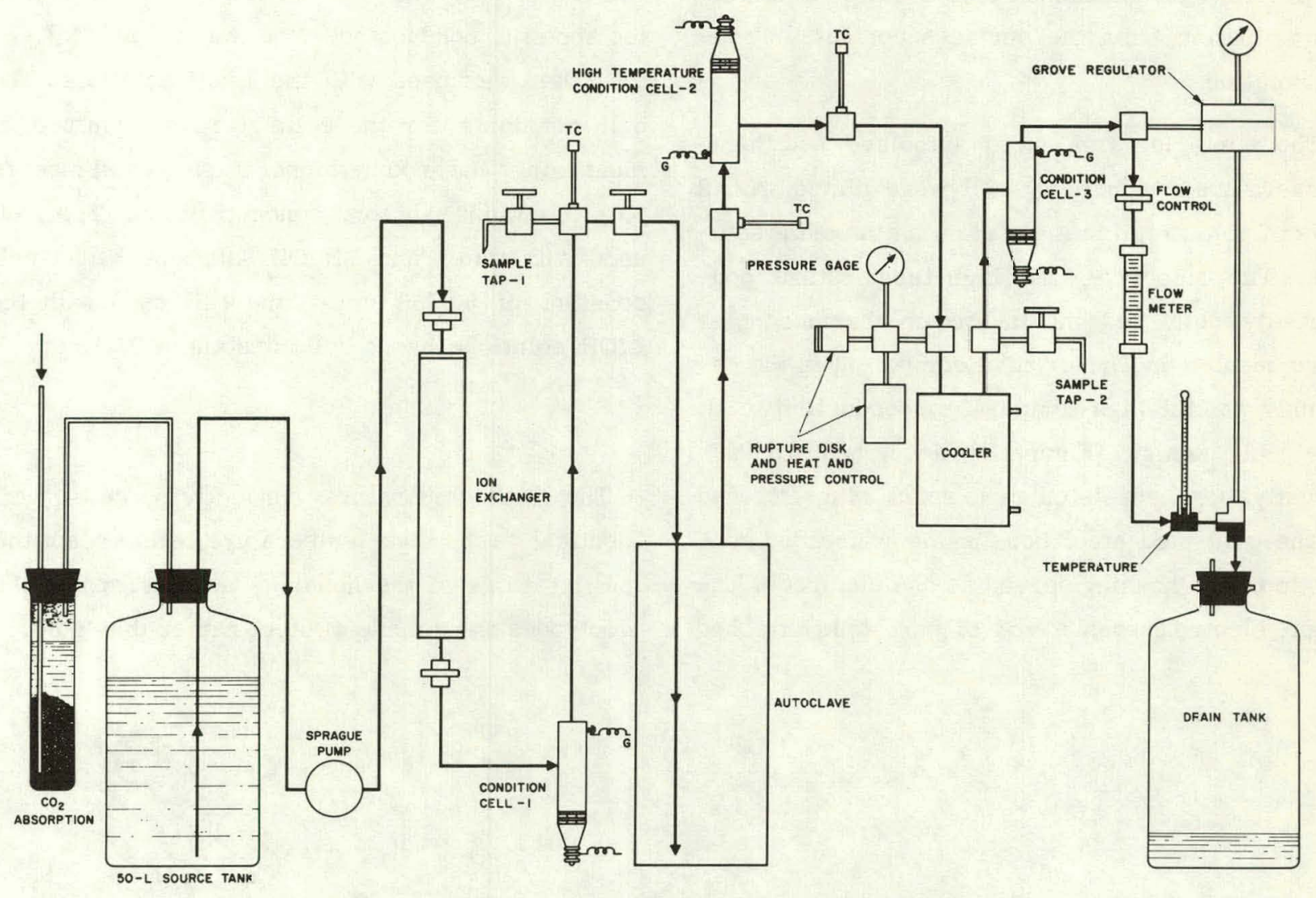

Figure 7. Schematic Arrangement of Apparatus 
heated, gold-Flated autoclave; a high-temperature, high-pressure conductivity cell; a cooler; a lowtemperature, high-pressure conductivity cell; a fow regulator valve; a flow meter; ard finally to drain. A regulazor set the system pressure at $2000 \mathrm{psi}$. The entire assembly was made as compact as practical to lessen heat losses and to minimize contamination from the surfaces contacted by the hot solution.

The interior of the autoclave and hightemperature conductirity cell were plated with 2 mils of gold to minimize contamination of the solution. The autoclave, the high-temperature conductivity cell, and the in-stream thermocouples were insulated. The critical componen: in the assembly was the high-temperature condustivity cell. The cell desigr. (Figure 8) developed for this investigation, consisted of a spark plig attached to the gold-clad steel housing by a. threaded connection. The housing served as one electrode. The other electrode was $\varepsilon$ rod of pure gold attached to a steel rod which extended from the bottom of the spark plug through the top of the plug and allowed electrical contact with the solution in the cell. The two electrodes were insulated from each other by the alumina part of the plug. Two different high-temperature cells were used in this work; one cell was used in the determinations of the specific conductances of water and $\mathrm{NH}_{4} \mathrm{OH}$, the other was used with the $\mathrm{Li} \supset \mathrm{H}$ solutions. The cell constants for the cells were determined by measuring the room-temperature resistance of $\mathrm{KCl}$ solutions at five concentrations. The cell used with water and $\mathrm{NH}_{4} \mathrm{OH}$ so:utions had a cell constant of $0.0566 \mathrm{~cm}^{-1}$; the cell used with the $\mathrm{LiOH}$ solutions had a cell constant of $0.219 \mathrm{~cm}^{-1}$.

The low-temperature conductivity cells were identical to the high-temperatur $=$ cells except that the interiors of the housings and the spark plug electrodes were made of steel rather than gold.

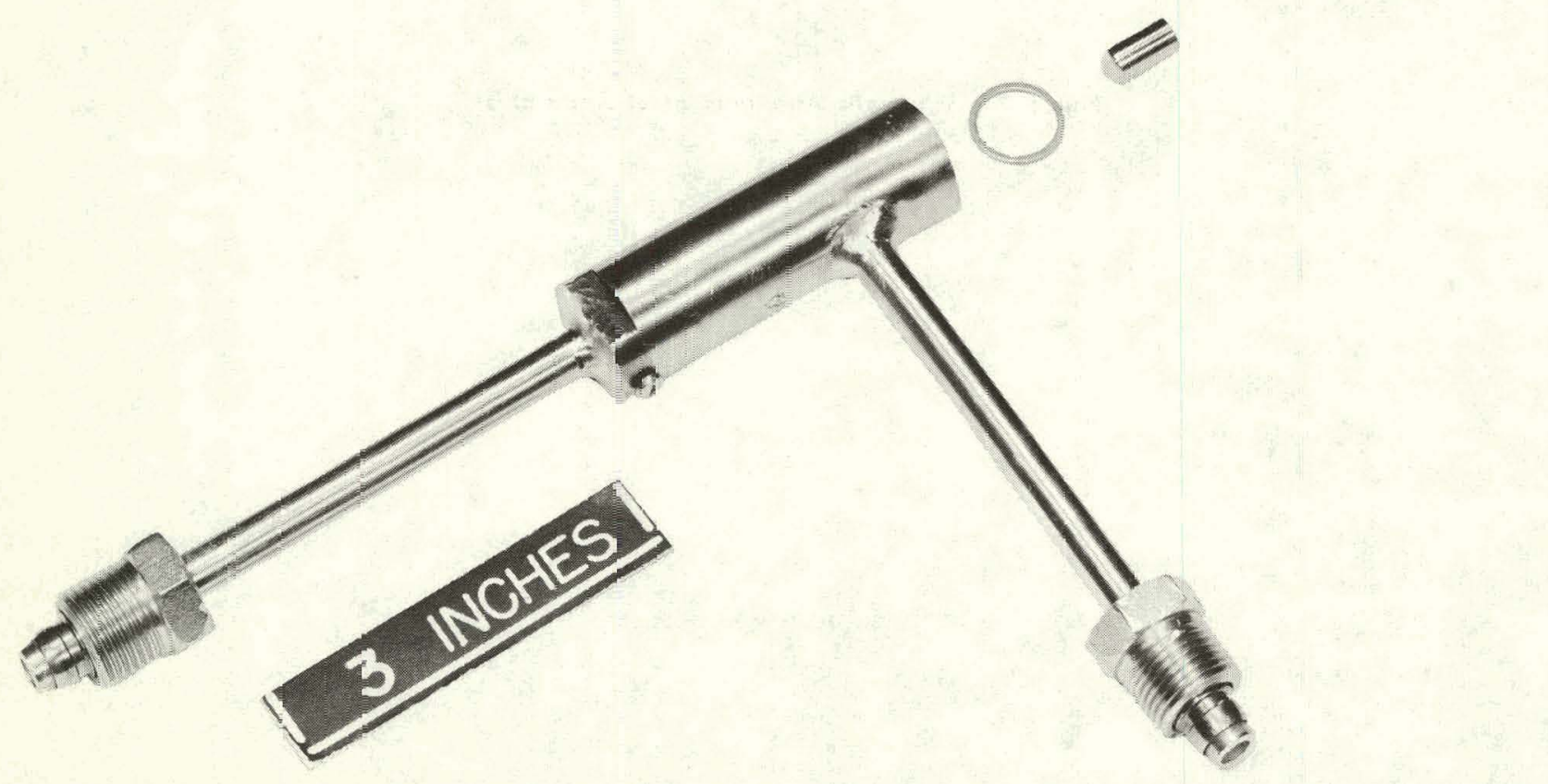

Figure 3. Component Parts of High-Temperature, High-Pressure Conductivity Cel' 
The leads from the conductivity cell electrodes were connected to a Type No. 650A Impedance Bridge manufactured by the General Radio Co. This instrument is accurate to 1.0 percent and operates at a frequency of $1000 \mathrm{cps}$. A Dumont cathode-ray oscilloscope was used as the detector.

\section{B. Operational Procedure}

Fifty liters of distilled water were placed in the source tank and nitrogen gas was bubbled through the water for about 30 minutes to remove $\mathrm{CO}_{2}$ and $\mathrm{O}_{2}$. A known quantity of the electrolyte solution was poured into the source tank and nitrogen gas was bubbled through the solution for about 30 minutes to assure complete mixing. The top of the source tank was capped and two polyethylene tubing leads were inserted through the cap. One lead was connected to the pump; the other lead was connected to a $\mathrm{CO}_{2}$ absorption bottle, which was partially filled with a LiOH solution.

While the solution was being mixed, the autoclave was drained, isolated by the flow control valve and the valve immediately before the autoclave, and evacuated. The valve before the autoclave was opened and the solution was allowed to fill the system. The flow control valve was set at $50 \mathrm{cc} / \mathrm{min}$. When the solution was shown to be of constant composition throughout the system (as indicated by the conductivity measurements on the three cells), the autoclave heaters were turned on and the temperature of the solution, measured at the autoclave outlet, was raised to $580 \mathrm{~F}$. When this temperature was reached, the autoclave heaters were turned off and the solution flow rate was increased from 50 to $200 \mathrm{cc} / \mathrm{min}$. This increase in rate essentially eliminated any temperature drop across the high-temperature conductivity cell. Conductance and temperature readings were made simultaneously every 3 to $10 \mathrm{~F}$ as the temperature decreased from $580 \mathrm{~F}$ to about $100 \mathrm{~F}$. The runs were usually terminated at this point. Low-tempercture conductance readings were taken to determine if contamination of the solutions occurred in the heated portion of the system.

During a run, samples of the solution were taken at the taps upstream of the autoclave and downstream of the cooler. Each sample was analyzed for the most conductive specie in the solution.

\section{The Specific Conductance of the Water}

Specific conductance measurements of the water used in preparing solutions were made over the temperature range of 100 to $570 \mathrm{~F}$ several times during the course of this work. These measurements served as a check on the cleanliness of the apparatus and are subtracted from the total measured conductivity of the solution in calculating the specific conductance of the electrolyte. It shculd be pointed out that these measurements do nct yield the correct conductance values of pure water at the elevated temperatures since: (1) the initial water contained some impurities, and (2) pickup of additional impurities occurred in the system.

The conductivity data obtained in each of the water runs are shown in Figure 9. The first three rurs were made prior to the $\mathrm{NH}_{4} \mathrm{OH}$ determirations. The fourth run was made between the $\mathrm{NH}_{4} \mathrm{OH}$ and LiOH determinations. The conductivity of the cooled water leaving the system is also shown.

D. Equivalent Conductances of $\mathrm{NH}_{4} \mathrm{OH}$ Solutions over the Temperature Range of 100 to $560 \mathrm{~F}$

The resistances of the $\mathrm{NH}_{4} \mathrm{OH}$ sclutions were measured over the room-temperature concentration range of 0.00473 to $0.0933 \mathrm{~N}$ and a temperature range of 100 to $560 \mathrm{~F}$. The equivalent conductances of the solutions were calculated using the standard definition of an equivalent conductance.

Figure 10 shows a plot of the data from each determination. The room-temperature concentrations of the $\mathrm{NH}_{4} \mathrm{OF}$ solutions were obtained by 


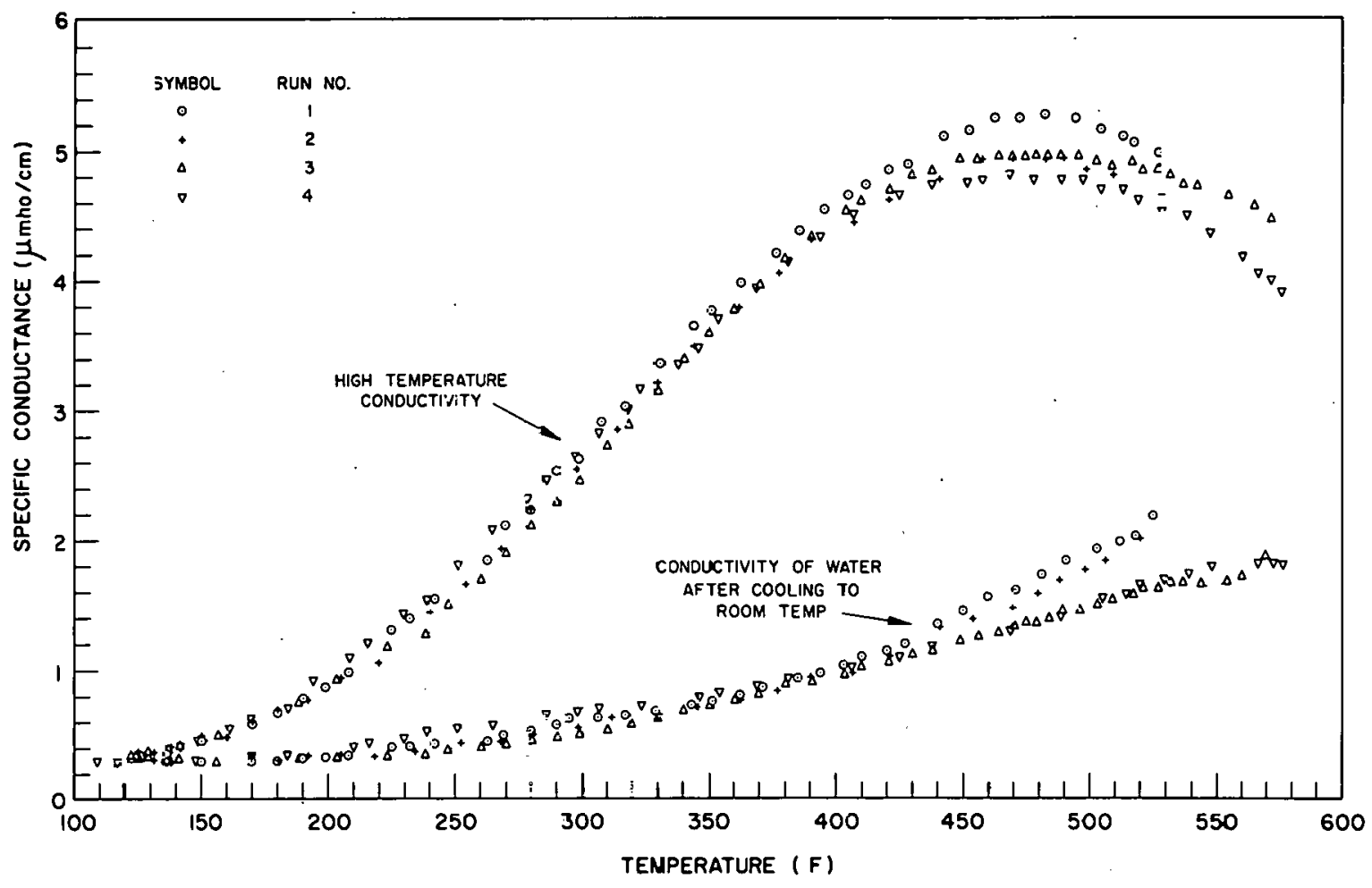

Figure 9. Specific Conciuctance of Water Used in the Experiments

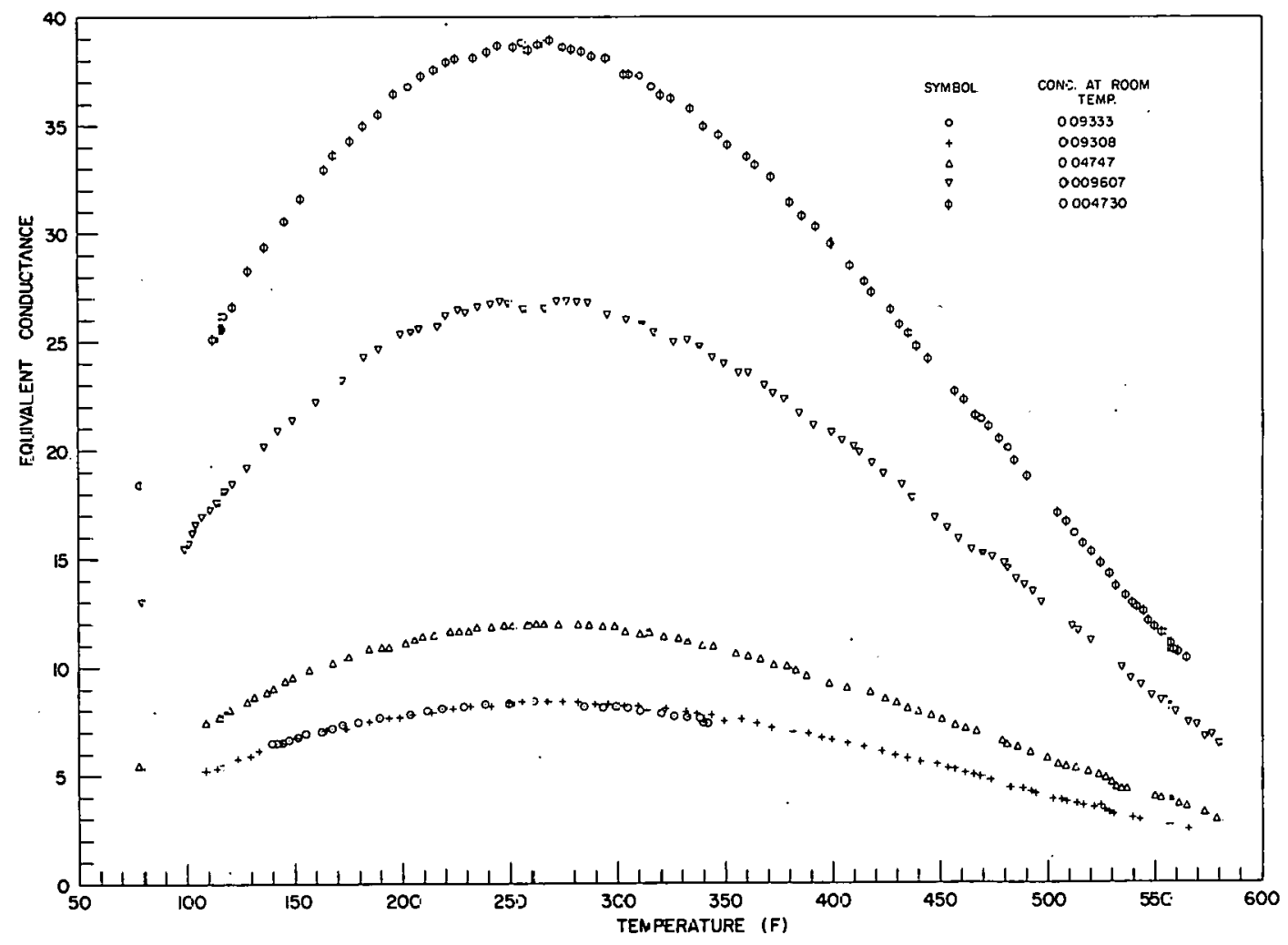

Figure 10. Jariation of the Equivalert Conductances of $\mathrm{NH}_{4} \mathrm{OH}$ Solutions with Temperature 
titration against standardized $0.1 \quad \mathrm{~N} \mathrm{H}_{2} \mathrm{SO}_{4}$ or standardized $0.01 \mathrm{~N} \mathrm{HCl}$ using methyl red as the indicator. The $\mathrm{NH}_{4} \mathrm{OH}$ concentrations remained essentially constant throughout all determinations. Baker and Adamson CP grade ammonium hydroxide was used in preparing the initial solutions.

E. Equivalent Conductances of $\mathrm{LiOH}$ Solutions Over the Temperature Range of 100 to $520 \mathrm{~F}$

The resistances of $\mathrm{LiOH}$ solutions were measured over the room-temperature concentration range of $0.00073 \mathrm{~N}$ to $0.0015 \mathrm{~N}$ and a solution temperature range of 100 to $520 \mathrm{~F}$. Since $\mathrm{LiOH}$ is a strong electrolyte, it was necessary to use very dilute solutions to maintain the conductance within reasonable limits.

The use of very dilute solutions introduced two difficulties: (1) Initially, titration of the solution to determine $\mathrm{OH}^{-}$concentration yielded erratic results. It was determined that the solutions were being contaminated by $\mathrm{CO}_{2}$ from the air during sampling and analysis. To prevent contamination, plastic hoods were placed around the sample taps and titration vessels to permit $\mathrm{N}_{2}$ blanketing of the samples at all times. Thereafter, titration results were reproducible to better than 1 percent. (2) The $\mathrm{OH}^{-}$concentration was not constant during a run. The changes were followed as a function of solution temperature by titrating samples taken periodically from the system. Plots were made of the roomtemperature concentrations as a function of solution temperature and the concentrations for any temperature were estimated by interpolation. It was difficult to decide whether the inlet concentration, the outlet concentrations, or an average of these should be used to calculate the equivalent conductances. The impurity (or impurities) which entered the solutions and tended to neutralize the $\mathrm{OH}^{-}$could have come from the thermal decomposition of nonionized, slightly soluble materials in the ion-exchange resins; or from surfaces of the heated autoclave, the high-temperature conductivity cell, or the steel tubing located between the hightemperature conductivity cell and the sooles. The interference by impurities was not appreciably decreased by increasing the flow rate of solution through the system. This indicated the concentration change occurred in the autoclave, which could not be adequately ficushed because of its large volume. If this is true, the resistance readings of the high-temperature cell were affected by the change. Therefore, the outlet concertration was chosen as the true concentration of the solution. The conductance data are shown in Figure 11.

F. Best Values for the Equivalent Corductances of $\mathrm{NH}_{4} \mathrm{OH}$ and $\mathrm{LiOH}$ At Temperature Intervals of $\underline{40 \mathrm{~F}}$

The best values of the equivalent conductances for the $\mathrm{NH}_{4} \mathrm{OH}$ solutions and the $\mathrm{LiOH}$ solutions at various concentrations and at temperature intervals of $40 \mathrm{~F}$ were obtained from smooth plots of the cata shown in Figures 10 and 11. The values obtainec are shown :n Tables IV and $\mathrm{V}$.

\section{G. The Behavior of LiOH Solutions at Elevated Temperatures}

Darken and Meier (Reference 13) measured the equivalent conductances of $\mathrm{LiOH}, \mathrm{NaOH}$, and $\mathrm{KOH}$ so.utions at $25 \mathrm{C}$ as a function of concentration and compared their ionization characteristics using the Shedlovsky test described in Section II-A. They found the $\Lambda^{\prime}$ 。 versus $\mathrm{C}$ plot for $\mathrm{LiOH}$ had a slight dip in it and concluded that $\mathrm{LiOH}$ behaves as a weak electrolyte. An ionization constant of 1.2 was calculated. $\mathrm{NaOH}$ showed very nearly complete ionization and the $\mathrm{KOH}$ showed complete ionization.

The Shedlovsky test was applied to the Bettis $\mathrm{LiOH}$ data using the equivalent conductance values shown in Table $V$. The $\Lambda^{\prime}$ o versis $C$ plots are skown in Figure 12. These plots show that the slopes of the lines became more negative as the temperature of the solution increased, indicating LiOH becomes less ionized as the solution temperature is increased. 


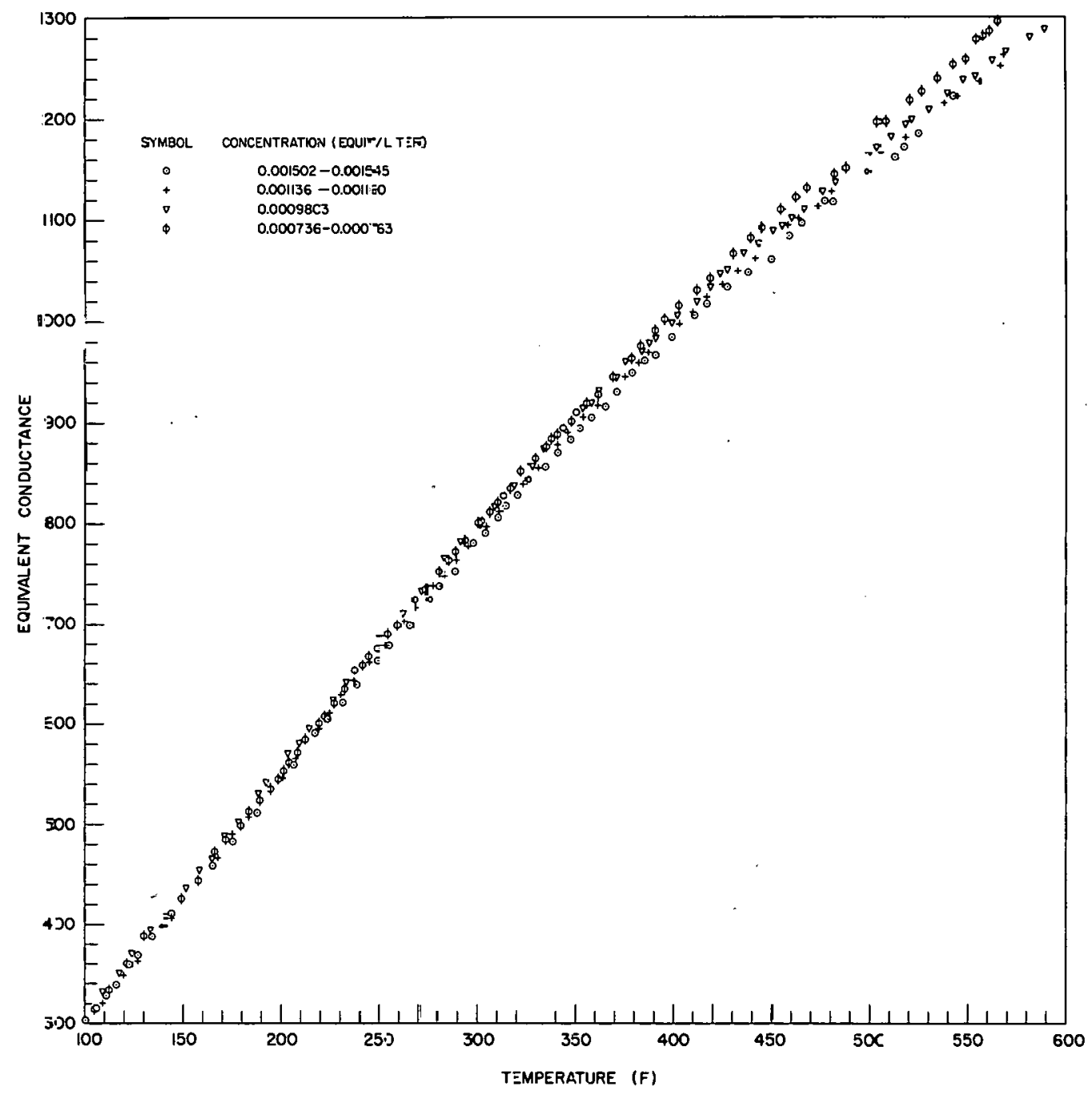

Figure 11. Variation of Equiralent Conductances of LiOH Solutions with Temperature 
TABLE IV

BEST VALUES FOR THE EQUIVALENT CONDUCTANCES OF $\mathrm{NH}_{4}$ OH SOLUTIONS AT VARIOUS TEMPERATURES AND CONCENTRATIONS

\begin{tabular}{|c|c|c|c|c|c|c|c|c|c|c|}
\hline \multirow[b]{2}{*}{$\begin{array}{c}\text { Temperature } \\
\text { (F) }\end{array}$} & \multicolumn{2}{|c|}{ Run 1} & \multicolumn{2}{|c|}{ Run 2} & \multicolumn{2}{|c|}{ Run 3} & \multicolumn{2}{|c|}{ Run 4} & \multicolumn{2}{|c|}{ Run 5} \\
\hline & $\begin{array}{c}\text { Equivalent } \\
\text { Conductance } \\
\text { (mho-cm } 2 / \text { eq) }\end{array}$ & $\begin{array}{c}\text { Conc. at } \\
\text { Temperature } \\
\text { (eq/liter) }\end{array}$ & $\begin{array}{c}\text { Equivalent } \\
\text { Conductance } \\
\left.\text { (mho-cm }{ }^{2} / \mathrm{eq}\right)\end{array}$ & $\begin{array}{c}\text { Conc. at } \\
\text { Temperature } \\
\text { (eq/liter) }\end{array}$ & $\begin{array}{c}\text { Equivalent } \\
\text { Conductance } \\
\text { (mho-cm } 2 \text { eq) }\end{array}$ & $\begin{array}{c}\text { Conc. at } \\
\text { Temperature } \\
\text { (eq/liter) }\end{array}$ & $\begin{array}{c}\text { Equivalent } \\
\text { Conductance } \\
\left.\text { (mho- } \mathrm{cm}^{2} / \mathrm{eq}\right)\end{array}$ & $\begin{array}{c}\text { Conc. at } \\
\text { Temperature } \\
\text { (eq/liter) } \\
\end{array}$ & $\begin{array}{c}\text { Equivalent } \\
\text { Conductance } \\
\text { (mho-cm } 2 / \text { eq) }\end{array}$ & $\begin{array}{c}\text { Conc. at } \\
\text { Temperature } \\
\text { (eq/liter) }\end{array}$ \\
\hline 80 & 4.13 & 0.09333 & - & - & - & - & 13.2 & 0.009604 & - & - \\
\hline 120 & 5.83 & 0.09203 & 5.70 & 0.09179 & 8.16 & 0.04682 & 18.3 & 0.009471 & 26.4 & 0.004665 \\
\hline 160 & 7.04 & 0.09122 & 7.01 & 0.09099 & 10.0 & 0.04641 & 22.2 & 0.009388 & 32.5 & 0.004624 \\
\hline 200 & 7.93 & 0.08990 & 7.80 & 0.08967 & 11.2 & 0.04574 & 25.2 & 0.009252 & 36.6 & 0.004557 \\
\hline 240 & 8.31 & 0.08820 & 8.31 & 0.08798 & 12.00 & 0.04488 & 26.8 & 0.009078 & 38.5 & 0.004471 \\
\hline 280 & 8.39 & 0.08649 & 8.48 & 0.08627 & 12.00 & 0.04400 & 26.9 & 0.008901 & 38.5 & 0.004384 \\
\hline 320 & 7,97 & ก.08461 & 8.16 & 0.08439 & 11.6 & 0.04305 & 25.4 & 0.008707 & 36.6 & 0.004288 \\
\hline 360 & & & 7.56 & 0.08230 & 10.5 & 0.04198 & 23.5 & 0.008492 & 33.7 & 0.004182 \\
\hline 400 & & & 6.73 & 0.07997 & 9.4 & 0.04079 & 20.8 & 0.008251 & 29.5 & 0.004064 \\
\hline 440 & & & 5.75 & 0.07750 & 8.0 & 0.03953 & 17.7 & 0.007997 & 24.8 & 0.003938 \\
\hline 480 & & & 4.68 & 0.07548 & 6.6 & 0.03804 & 14.6 & 0.007696 & 20.2 & 0.003790 \\
\hline 520 & & & 3.59 & 0.07122 & 5.17 & 0.03633 & 11.2 & 0.007348 & 15.4 & 0.003619 \\
\hline 560 & & & 2.64 & 0.06711 & 3.74 & 0.03423 & 7.95 & 0.006924 & 10.9 & 0.003410 \\
\hline
\end{tabular}


'I'ABLE' V

BEST VALUES FOR TIIE EQUIVALENT CONDUCTANCES OF LIOH SOLUTIONS AT VARIOUS TEMPERATURES AND CONCENTRATIONS

\begin{tabular}{|c|c|c|c|c|c|c|c|c|}
\hline \multirow[b]{2}{*}{$\begin{array}{l}\text { Temperature } \\
\text { (F) }\end{array}$} & \multicolumn{2}{|c|}{ Run 1} & \multicolumn{2}{|c|}{ Run 2} & \multicolumn{2}{|c|}{ Run 3} & \multicolumn{2}{|c|}{ Run 4} \\
\hline & $\begin{array}{c}\text { Equivalent } \\
\text { Conductance } \\
\text { (mho-cm } 2 / \text { eq) }\end{array}$ & $\begin{array}{l}\text { Conc. at } \\
\text { Temperature } \\
\text { (eq/liter) }\end{array}$ & $\begin{array}{c}\text { Equivalent } \\
\text { Conductance } \\
\text { (mho-cm } 2 / \text { eq) }\end{array}$ & $\begin{array}{l}\text { Conc. at } \\
\text { Temperature } \\
\text { (eq/liter) }\end{array}$ & $\begin{array}{l}\text { Equivalent } \\
\text { Conductance } \\
\text { (mho/cm²/eq) }\end{array}$ & $\begin{array}{c}\text { Conc. at } \\
\text { Temperature } \\
\text { (eq/liter) }\end{array}$ & $\begin{array}{c}\text { Equivalent } \\
\text { Conductance } \\
\left.\text { (mho/cm } / \mathrm{cm}^{2} / \mathrm{eq}\right)\end{array}$ & $\begin{array}{c}\text { Conc. at } \\
\text { Temperature } \\
\text { (eq/liter) }\end{array}$ \\
\hline 120 & 350 & 0.001524 & 347 & 0.001143 & 359 & 0.0009668 & 352 & 0.0007525 \\
\hline 160 & 448 & 0.001510 & 448 & 0.001131 & 459 & 0.0009583 & 453 & 0.0007458 \\
\hline 200 & 546 & 0.001488 & 548 & 0.001113 & 559 & 0.0009444 & โร? & 0.0007351 \\
\hline 240 & 644 & 0.001460 & 650 & 0.001089 & 660 & 0.0009266 & 655 & 0.0007198 \\
\hline 280 & 737 & 0.001432 & 744 & 0.001066 & 757 & 0.0009085 & 754 & 0.0007025 \\
\hline 320 & 828 & 0.001398 & 833 & 0.001041 & 844 & 0.000888 & 844 & 0.0006845 \\
\hline 360 & 911 & 0.001360 & 919 & 0.001014 & 929 & 0.0008668 & 930 & 0.0006649 \\
\hline 400 & 990 & 0.001317 & 996 & 0.0009832 & 1002 & 0.0008422 & 1012 & 0.0006435 \\
\hline 440 & 1057 & 0.001272 & 1064 & 0.0009512 & 1076 & 0.0008162 & 1087 & 0.0006211 \\
\hline 480 & 1122 & 0.001220 & 1130 & 0.0009138 & 1137 & 0.0007855 & 1157 & 0.0005954 \\
\hline 520 & 1178 & 0.001159 & 1190 & 0.0008711 & 1200 & 0.0007500 & 1220 & 0.0005660 \\
\hline
\end{tabular}




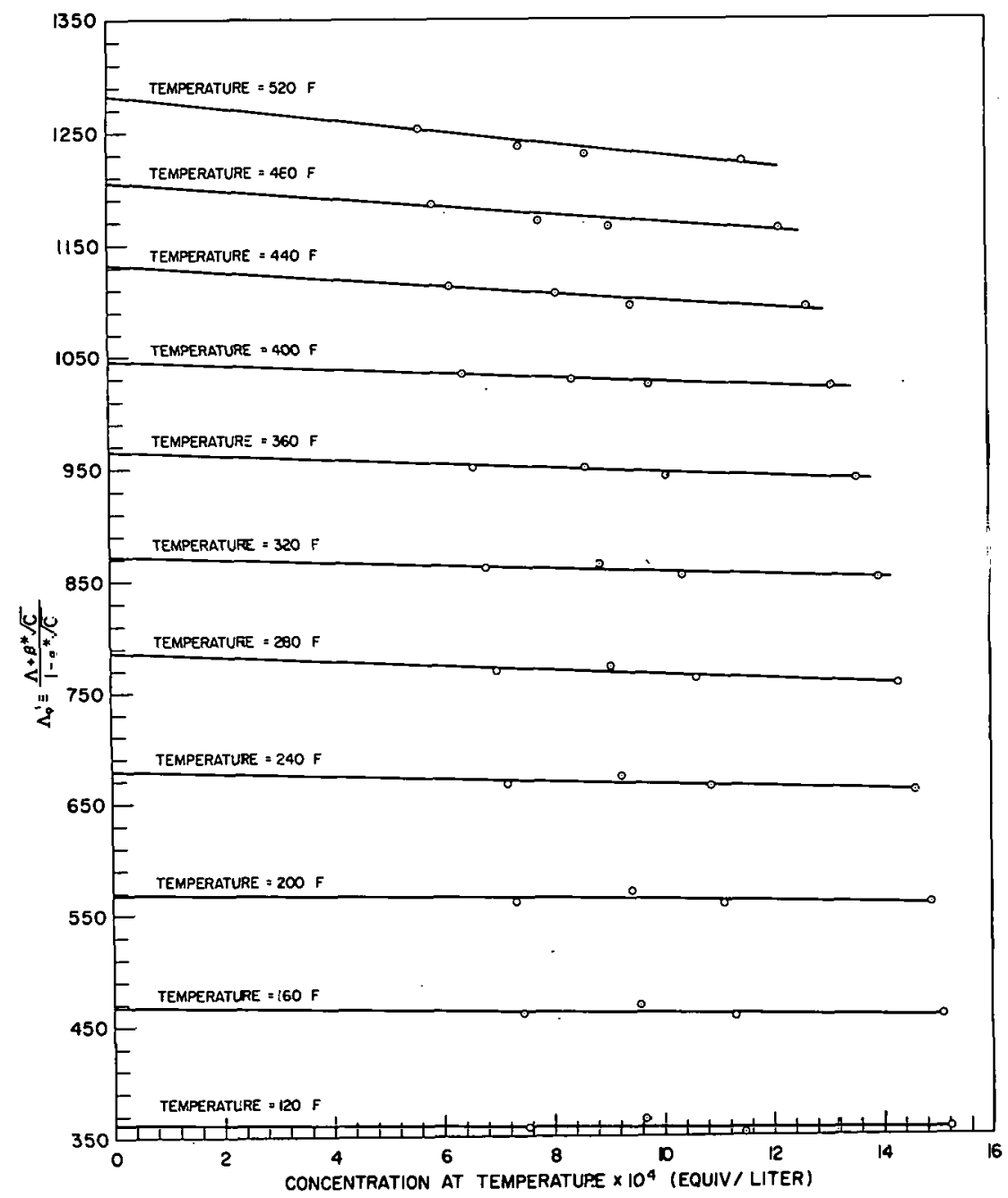

Figure 12. Shedlovsky Test for the Ionization of LiOH Solutions

The equivalent conductances at infinite dilution and the ionization constants were computed using the method outlined in Section II-C. The final results are shown in Table VI. The $\Lambda \mathrm{S}(\mathrm{Z})$ versus $\alpha^{2} C \gamma_{ \pm}^{2}$ plots and the change in the ionization constants with temperature are shown in Figures 13 and 14 , respectively.

It is clear from the $K$ versus temperature plot (Figure 14) that the number of $\mathrm{Li}^{+}$and $\mathrm{OH}^{-}$ions in solution decreases as the temperature of the solution increases. The theory of Bjerrum presented in Section II-D was used to determine whether
TABLE VI

EQUIVALENT CONDUCTANCES AT INFINITE DILUTION AND THE IONIZATION CONSTANTS FOR LIOH AT TEMPERATURES FROM $120 \mathrm{~F}$ to $520 \mathrm{~F}$

\begin{tabular}{|c|c|c|}
\hline $\begin{array}{l}\text { Temperature } \\
\text { (F) }\end{array}$ & $\begin{array}{c}\Lambda^{\circ} \\
\text { (mho-cm } 2 / \text { eq) } \\
\end{array}$ & ( $\mathrm{K}$ molar scale) \\
\hline 120 & 360.7 & 0.128 \\
\hline 160 & 466.7 & 0.0685 \\
\hline 200 & 569.1 & 0.0742 \\
\hline 240 & 679.1 & 0.0456 \\
\hline 280 & 786.1 & 0.0310 \\
\hline 320 & 873.9 & 0.0435 \\
\hline 360 & 965.1 & 0.0396 \\
\hline 400 & 1046 & 0.0414 \\
\hline 440 & 1133 & 0.0255 \\
\hline 480 & 1206 & 0.0234 \\
\hline 520 & 1283 & 0.0172 \\
\hline
\end{tabular}




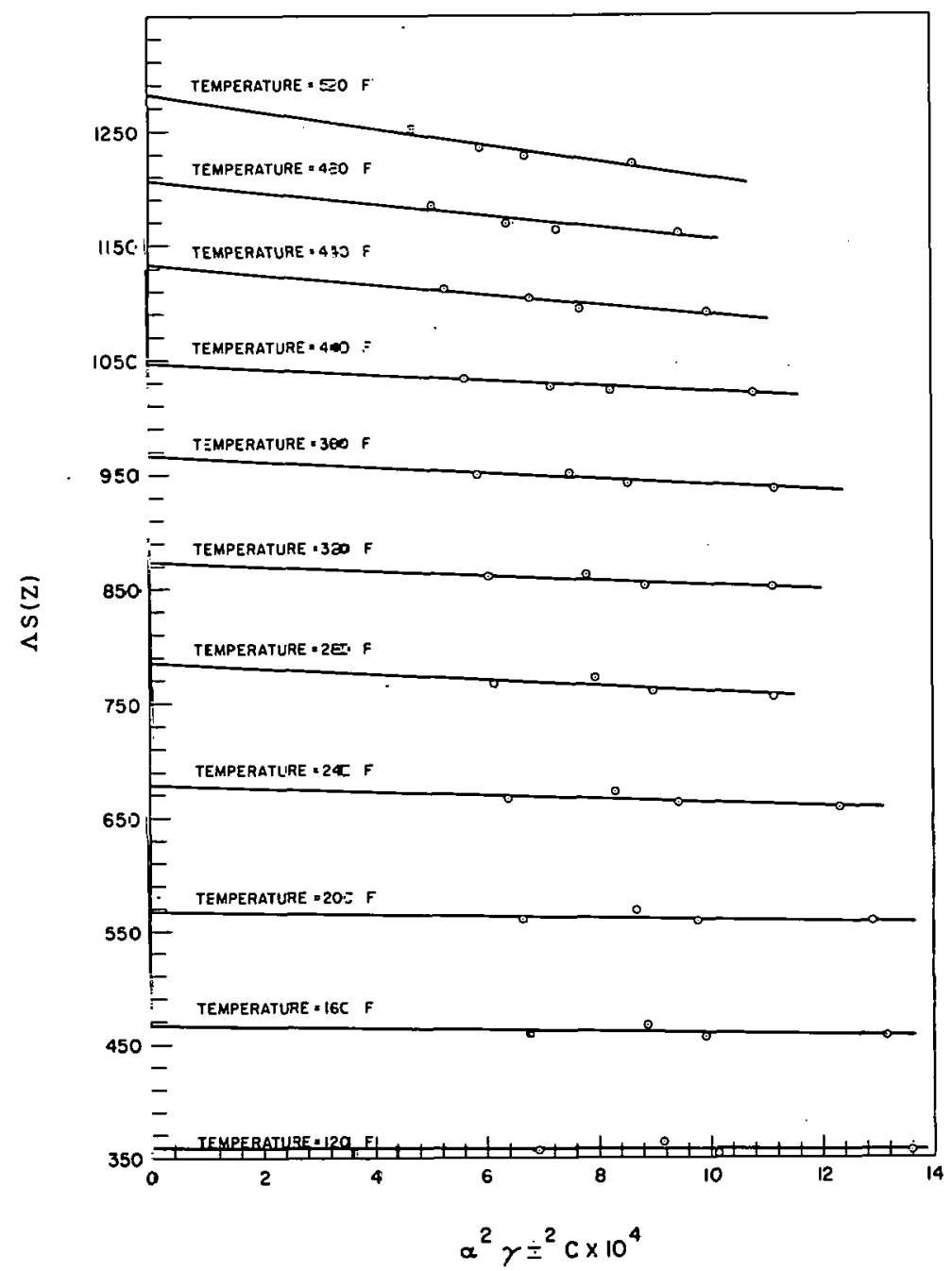

Figure 13. Determinatior of $\Lambda^{D}$ and $K$ by $\Lambda S(Z)$ Versus $a^{2} \gamma^{2} \pm$ C Plat

this decrease could be carsed by ion-pair for mation. The $\underline{a}$ values and the cistances, $q$, at which the probability function possesses a minimum are shown in Table vil. This tabls shows the calculated a values are less than the sum of the ioric radii, indicating that some force in addition to sir-ple ionion attraction is probably operative between the $\mathrm{Li}^{+}$ and $\mathrm{OH}^{-}$ions.

Johnston (Refererce 15) showed from th: Nojes conductance data that a lo:s-losplot of the equitalent conductances at infinite dilution for salts versus viscosities of water at var:ous temperatures yieiced straight lines, and furtt:er noted that bases and acids did not follow this relationship. Figure 15 illusirates this plot. The Bett:s LiOH data follows this relationship as shown in Figure 16. The equation relating the $\Lambda^{\circ}$ for $\mathrm{LiOH}$ and the viscosity of water is:

$$
\Lambda^{\circ}=7.4 \eta_{0}^{-0.75}
$$

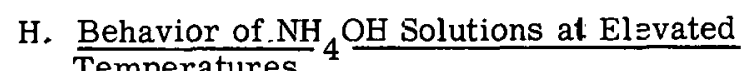
Temperatures

The conductances of $\mathrm{NH}_{4} \mathrm{OH}$ solutions were measured by A. A. Noyes (Reference 1) at 212, 313, 424, and $583 \mathrm{~F}$. The method consisted of: (1) placing an ammonium hydroxide solution of known concentration in a platinum lined autoclave and measuring the room temperature $(18 \mathrm{C})$ conductance of the solution; (2) heating the solution to some predetermined temperature and measuring the conductance, and (3) cooling the solution to roam temperature and remeasuring the conductance. The best 


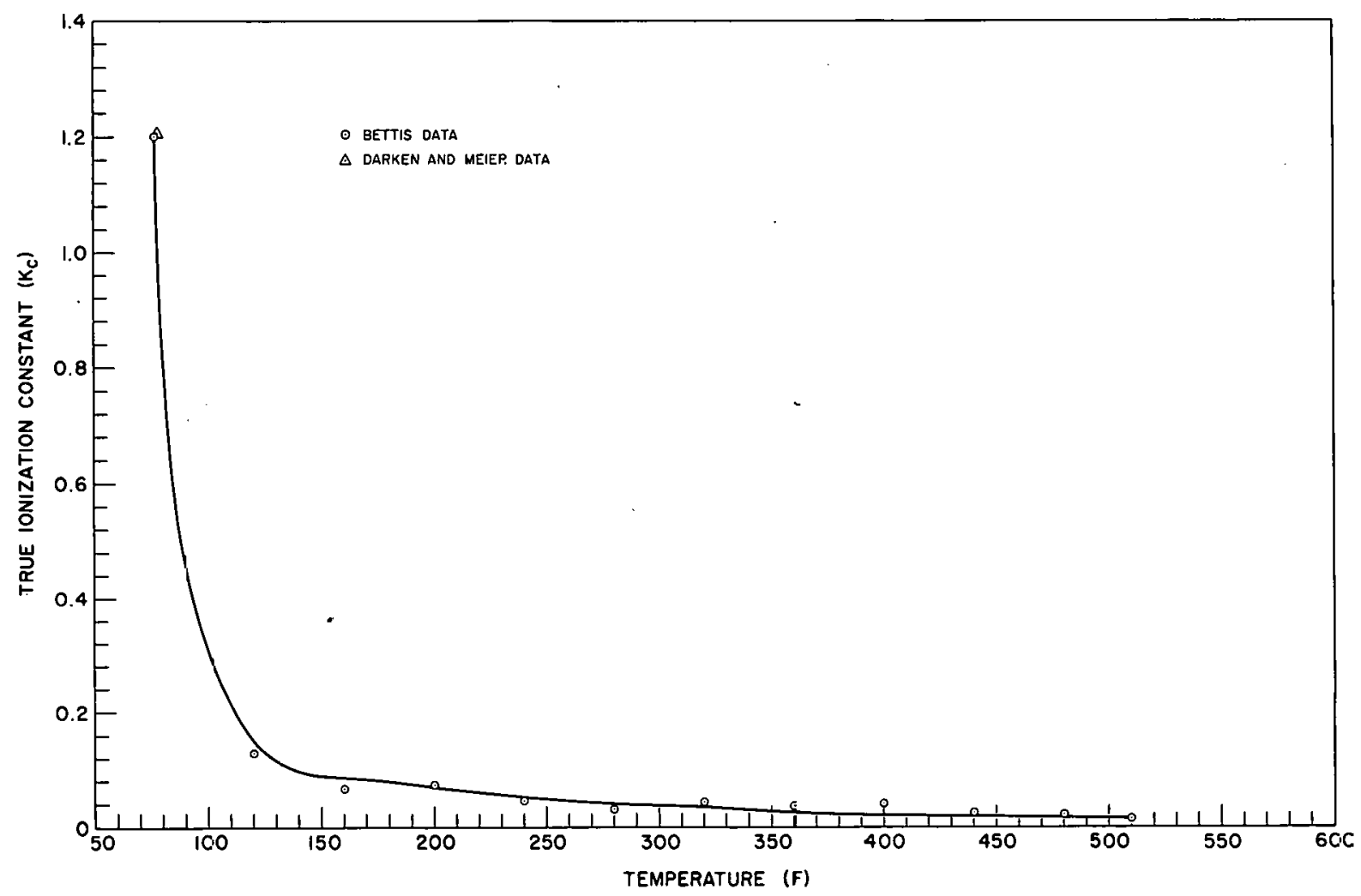

Figure 14. Variation of Ionization Consfant of LiOH with Temperature

TABLE VII

CALCULATED MEAN DISTANCES OF CLOSEST APPROACH FOR LiOH

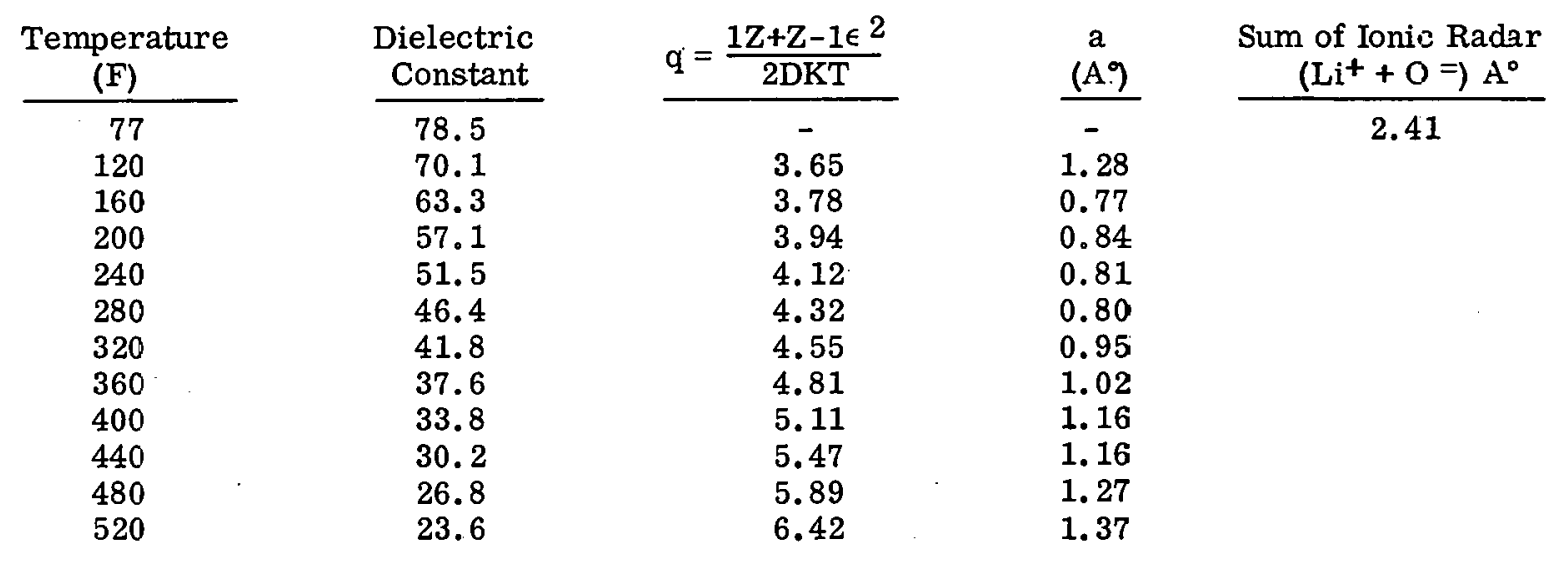

value data of Noyes are compared against the Bettis best value data in Table VIII. The percentage difference between the two sets of data was seen to increase with increasing temperature. This indicated impurities were leaching into the Bettis solutions or decomposition was taking place in the Noyes solutions. Noyes observed that the final room-temperature conductances of his solutions were less than the initial conductances and attributed this change to a catalytic oxidation of $\mathrm{NH}_{4} \mathrm{OH}$ $b$ the platinum lining of the autoclave:

$$
4 \mathrm{NH}_{4} \mathrm{OH}+3 \mathrm{O}_{2}=2 \mathrm{~N}_{2}+10 \mathrm{H}_{2} \mathrm{O} \text {. }
$$




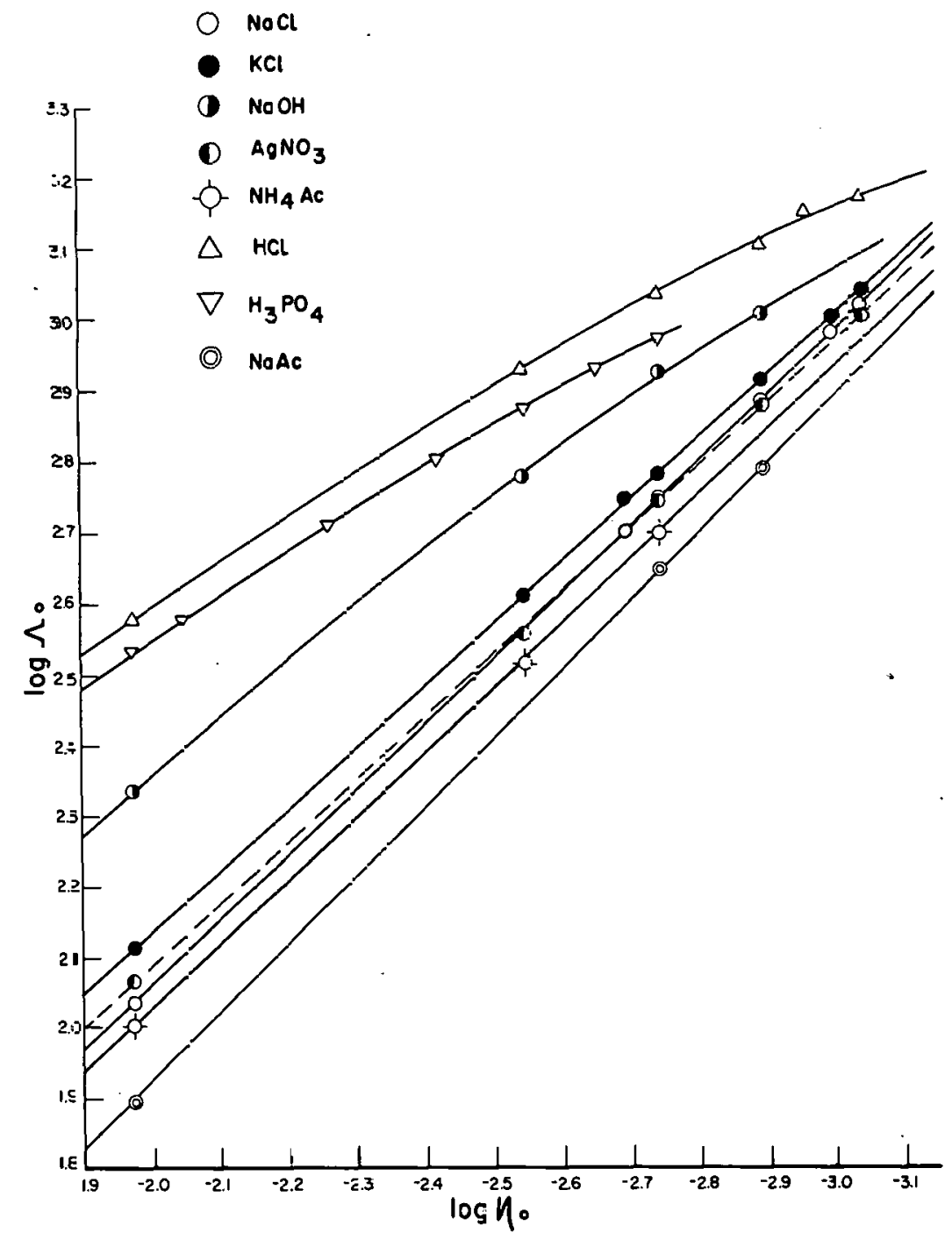

Figure 15. $\log \Lambda_{0}$ Viersus Log $\eta_{0}$ for Several Electrolytes

TABLE VIII

BEET VALUES FOR THE EQUT'A IENT CONDUCTANCES OF NH 4 CH SOLUTIONS OBTAINED BY A. A, NOYES AND BETTIS

\begin{tabular}{|c|c|c|c|c|}
\hline \multirow{2}{*}{$\begin{array}{l}\text { Temperanure } \\
\text { (F) }\end{array}$} & \multirow{2}{*}{$\begin{array}{l}\text { Concentration } \\
\text { at Temperature } \\
\text { (equiv/liter) }\end{array}$} & \multicolumn{2}{|c|}{ Equivalent Conductance } & \multirow{2}{*}{$\begin{array}{c}\text { \% Difference } \\
\text { (Bettis-Noyes) }\end{array}$} \\
\hline & & Bettis Data & Noyes Data & \\
\hline 212 & $\begin{array}{l}0.0100 \\
0.0400 \\
0.0900\end{array}$ & $\begin{array}{c}24.6 \\
12.1 \\
8.03\end{array}$ & $\begin{array}{l}23.5 \\
11.8 \\
7.84\end{array}$ & $\begin{array}{l}4.5 \\
2.5 \\
2.4\end{array}$ \\
\hline 313 & $\begin{array}{l}0.0100 \\
0.0400 \\
0.0900\end{array}$ & $\begin{array}{c}24.1 \\
12.0 \\
7.94\end{array}$ & $\begin{array}{c}21.7 \\
11.2 \\
7.55\end{array}$ & $\begin{array}{r}10.0 \\
6.7 \\
4.9\end{array}$ \\
\hline 424 & $\begin{array}{l}0.0100 \\
0.0400 \\
0.0900\end{array}$ & $\begin{array}{c}17.2 \\
8.58 \\
5.71\end{array}$ & $\begin{array}{c}15.4 \\
7.63 \\
5.08\end{array}$ & $\begin{array}{l}10.5 \\
11.1 \\
11.0\end{array}$ \\
\hline
\end{tabular}




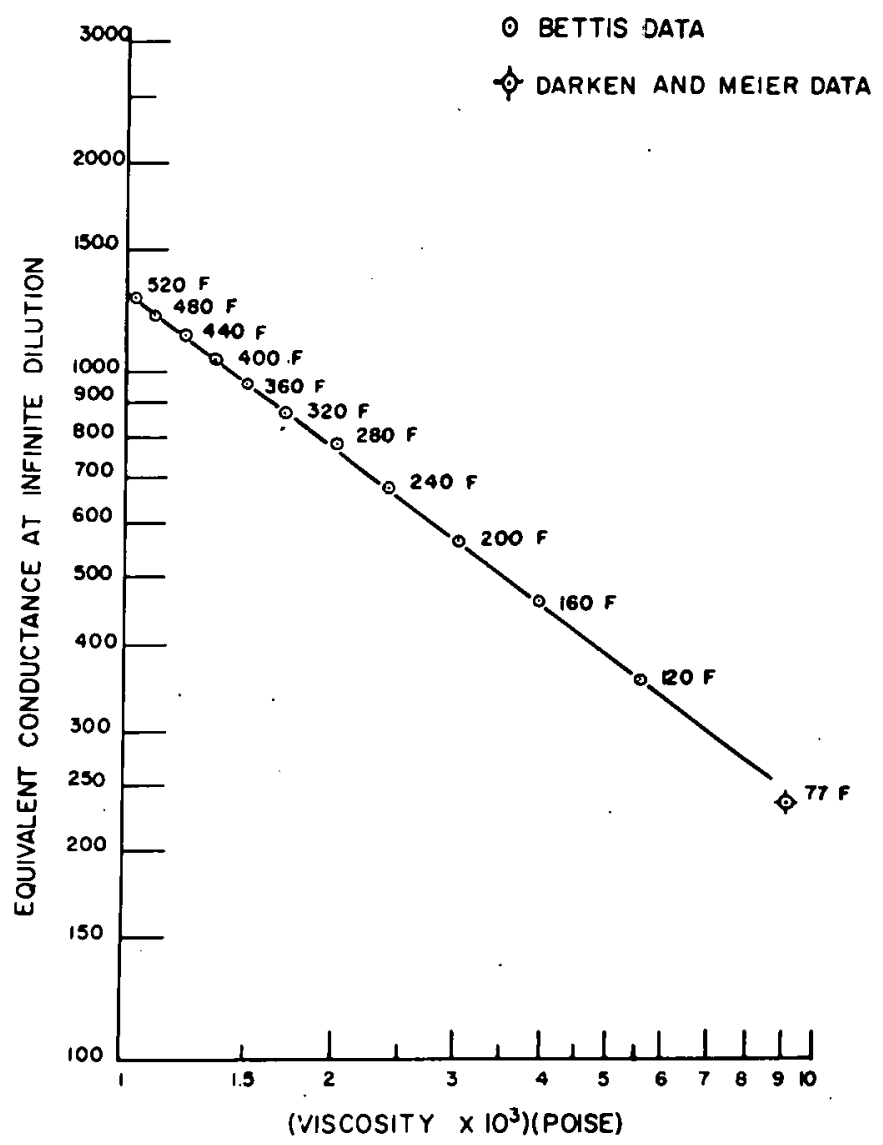

Figure 16. Variation of the Equivalent Conductances of LiOH at Infinite Dilution with the Viscosify of the Solvent

The conductance decrease amounted to about 1 percent for the solutions heated to $212 \mathrm{~F}$ and to about 2 percent for the solutions heated to $424 \mathrm{~F}$. The Bettis analyses showed no apparent change in $\mathrm{NH}_{4} \mathrm{OH}$ concentration on passage through the goldlined system.

The $\Lambda^{\circ}$ and $\mathrm{K}$ values for $\mathrm{NH}_{4} \mathrm{OH}$ cannot be determined by the method described for $\mathrm{LiOH}$ since the equivalent conductance values for $\mathrm{NH}_{4} \mathrm{OH}$ are about two orders of magnitude less than the limiting conductances, $\Lambda^{\circ}$, and extrapolation of the data to $\mathrm{C}=\mathrm{O}$ is very inaccurate. The $\Lambda^{\circ}$ valueswere determined using the Noyes $\Lambda^{\circ}$ values for $\mathrm{NaOH}$, $\mathrm{NH}_{4} \mathrm{Ac}$, and $\mathrm{NaAc}$ at various temperatures and the Kohlrausch limiting conductance law. The dissociation constants were determined by substituting the $\mathrm{NH}_{4} \mathrm{OH}$ best value data (Table IV) into Equations (8) and (9) and solving for $\alpha$; then, solving for $\gamma \pm$ using Equation (15) and substituting the $\alpha$ and $\gamma \pm$ values into Equation (13). The final $\Lambda^{\circ}$ and $\mathrm{K}$ values at various temperatures are shown in Takle $\mathrm{CX}$.

\section{THE ION-PRODUCT OF WATER AT ELEVATED TEMPERATURES}

Fieretofore, all reactor coolant data have been related to the room-temperature $\mathrm{pH}$ of reactor coolants. One of the main purposes cf this report is to determine the true $\mathrm{pH}$ of reactor coosants at reactor temperatures. The ion-product of water must be known before these values can be detėrmined.

Noyes, Kato, and Sosman (Reference 13) have determined the ion-product of water at elevated temperatures by a series of experiments which consisted of: (1) measuring the conductances of solutions containing a hydrolyzable salt at different initial salt concentrations, and (2) measuring the conductances of solutions of the hydrolyzable salt mixed with added amounts of one of the hydrolysis products. The addition of the hydrolysis product represses the hydrolysis of the salt, and the conductance measured is essentially that conductance which the salt would have if it did not hydrolyze. The difference in conductances found in steps (1) and (2) is a measure of the hydrolysis of the salt.

TABLE IX

$\Lambda^{\circ}$ AND K VALUES FOR $\mathrm{NH}_{4} \mathrm{OH}$ AT VARIOUS TEMPERATURES

\begin{tabular}{|c|c|c|}
\hline Temperature, (F) & $\Lambda^{\circ}$ & $\underline{K \text { (molar units) }}$ \\
\hline 120 & 387 & $2.08 \times 10^{-5}$ \\
\hline 160 & 507 & $1.79 \times 10^{-}$ \\
\hline 200 & 618 & $1.49 \times 10^{-5}$ \\
\hline 240 & 727 & $1.13 \times 10^{-5}$ \\
\hline 280 & 827 & $9.05 \times 10^{-6}$ \\
\hline 320 & 927 & $6.41 \times 10^{-6}$ \\
\hline 360 & 1023 & $4.39 \times 10^{-6}$ \\
\hline 400 & 1110 & $2.82 \times 10^{-6}$ \\
\hline 440 & 1192 & $1.75 \times 10^{-6}$ \\
\hline 480 & 1262 & $9.98 \times 10^{-7}$ \\
\hline 520 & 1326 & $6.16 \times 10^{-7}$ \\
\hline 560 & 1380 & $2.40 \times 10^{-7}$ \\
\hline
\end{tabular}


The ion-produzt of water is calculated using the hydrolysis constant of the salt and the ionization ccinstants of tre hydrolysis products. Tajle X lists the Noyes $K_{w}$ values for water at five different temperatures. These $\mathrm{K}_{\mathrm{w}}$ values in Table $\mathrm{X}$ may nct be accurate since a close examination of the data shows that in some cases insufficient amounts of the hydrolysis products were added for complete suppression of the salt hydrolysis. Several different approaches were taken in an attempt to recalculate the ion products from the data; however, none of the methods appeared to be improvements over the empirical method of Noyes and until more experimental data are available to obtain a more accurate expression to represent changes in conduztance of mistures, the values for the icn-product for water, listed in Tajle $X$, will have to be used.

V. CHANGE $: \mathrm{N}$ THE $\mathrm{pH}$ OF $\mathrm{H}_{2} \mathrm{O}, \mathrm{L}: \mathrm{OH}$, AND $\mathrm{NH}_{4} \mathrm{OH}$ SOLUTIONS WITH TEMPERATURE

The $\mathrm{pH}$ of pure water at various temperatures was calculated ising the equation,

$$
\mathrm{pH}=-\log \left(\mathrm{H}^{+}\right)=-\log \mathrm{K}_{\mathrm{w}}^{1 / 2},
$$

in which $\left(\mathrm{H}^{+}\right)$represen:s the molar hydroger ion concentration. The $\mathrm{K}_{\mathrm{w}}$ ralues at various temperatures are shown in Table $\mathrm{X}$.

The proceduze used to calculate the $\mathrm{pH}$ of $\mathrm{LiOH}$ anc $\mathrm{NH}_{4} \mathrm{OH}$ solutions at various temperatures was:

1) Assume an ammonium hydroxide or lithium hydroxide solution to have a certain $\mathrm{pH}$ at room temperature.

\section{.TABLE X}

THE ION-PRODUET OF WATER

AT VARIOUS TEMPERATURES

\begin{tabular}{|c|c|c|}
\hline \multicolumn{2}{|c|}{ Temperajure } & Ion-Product of Water \\
\hline (C) & (F) & $\mathrm{K}_{\mathrm{w}}$ \\
\hline 18 & 64.4 & $0.64 \times 10^{-14}$ \\
\hline 100 & 212 & $4.8 \times 10^{-13}$ \\
\hline 156 & 313 & $2.23 \times 10^{-12}$ \\
\hline 218 & 424 & $4.61 \times 10^{-12}$ \\
\hline 306 & 58.3 & $1.68 \times 10^{-12}$ \\
\hline
\end{tabular}

2) From the assumed $\mathrm{pH}$ and the equation

$\mathrm{pH}=-\log \left(\mathrm{H}^{+}\right)$

calculate the $\left(\mathrm{H}^{+}\right)$concentration.

3) From the relationships

$$
\begin{aligned}
& \mathrm{K}_{\mathrm{W}}=\left(\mathrm{H}^{+}\right)\left(\mathrm{OH}^{-}\right) \\
& \mathrm{K}_{\text {Base }}=\frac{\left(\mathrm{M}^{+}\right)\left(\mathrm{OH}^{-}\right)}{(\mathrm{MOH})} \\
& \left(\mathrm{OH}^{-}\right)=\left(\mathrm{M}^{+}\right)+\left(\mathrm{H}^{+}\right) \\
& \left(\mathrm{M}^{+}\right)=\alpha \mathrm{C} \\
& (\mathrm{MOH})=\mathrm{C}(1-\alpha \vdots
\end{aligned}
$$

in which the molar concentration of the base is $\mathrm{C}$ and $\alpha$ is the degree of ionization of the base, it can be shown that:

$$
\alpha=\frac{\mathrm{K}_{\text {Base }}}{\mathrm{K}_{\text {Base }}+\frac{\mathrm{K}_{x}}{\left(\mathrm{H}^{+}\right)}},
$$

and

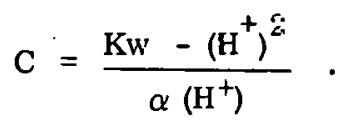

Substitute the room-temperature values for $\mathrm{K}_{\text {Base }}, \mathrm{K}_{\mathrm{W}}$, and $\left(\mathrm{H}^{+}\right)$into Equation (28) and solve for $\alpha$. Substitute $\alpha$ into Equation (2S) and solve for $\mathrm{C}$.

4) Determine the concentration of the solution at various temperatures by dividing the specific volume of the solution at the various temperatures into the rocm temperature concentration, $\mathrm{C}$.

5) From the relationsinips listed in step (3), it can be shown that

$$
\begin{gathered}
\mathrm{K}_{\text {Base }}\left(\mathrm{H}^{+}\right)^{3}+\left(\mathrm{K}_{\mathrm{w}}+\mathrm{K}_{\text {Base }} \cdot \mathrm{C}\right)\left(\mathrm{H}^{+}\right)^{2}- \\
\mathrm{K}_{\mathrm{w}} \cdot \mathrm{K}_{\text {Base }}\left(\mathrm{H}^{+\frac{1}{\mathrm{l}}}\right)=\mathrm{K}_{\mathrm{w}}{ }^{2}:
\end{gathered}
$$

Use the values for $\mathrm{K}_{\mathrm{Base}}, \mathrm{C}$, and $\mathrm{K}_{\mathrm{w}}$ at the temperature in question, and calculate $\left(\mathrm{H}^{+}\right)$. 
6) Substitute $\left(\mathrm{H}^{+}\right)$into Equation (22) and calculate the $\mathrm{pH}$ of the solution.

Table XI and Figure 17 show the pH values of neutral water at various temperatures, the $\mathrm{pH}$ values for $\mathrm{NH}_{4} \mathrm{OH}$ solutions having a room temperature $\mathrm{pH}$ of 8.0 and 9.5, and the $\mathrm{pH}$ values of $\mathrm{LiOH}$ solutions having room temperature $\mathrm{pH}$ values of 9.0 and 10.5 .

It is clear from this table that, for the $\mathrm{NH}_{4} \mathrm{OH}$ concentrations specified for reactor coolants, the coolant at reactor temperatures is more basic than neutral water $(\mathrm{pH}=5.75)$ by only $0.5 \mathrm{pH}$ unit, whereas, a reactor coolant containing $\mathrm{LiOH}$ is 1.5 to $2 \mathrm{pH}$ units more basic than neutral water. Differences in concentrations of insoluble corrosion products found in the two coolants may well be attributed to this difference in basicity of the solutions. Suspensoids are very sensitive to changes in environment and additions of electrolytes can easily cause flocculation or agglomeration and settling. The corrosion mechanism may also be directly affected by the $\mathrm{pH}$ of the solution. The added basicity in $\mathrm{LiOH}$ coolants may be the direct cause for the lower levels of suspended corrosion products observed in plants using this coolant as opposed to plants using coolant containing $\mathrm{NH}_{4} \mathrm{OH}$.

\section{SUMMARY AND CONCLUSIONS}

A. Criteria applied to room-temperature conductances for determining complete ionization of 1-1 electrolytes were applied to the A. A. Noyes high-temperature conductance data obtained on $\mathrm{NaCl}, \mathrm{HCl}, \mathrm{KCl}, \mathrm{NaOH}, \mathrm{AgNO}_{3}$, and $\mathrm{H}_{3} \mathrm{PO}_{4}$ solutions. It was found that the first four electrolytes behave as strong electrolytes up through temperatures of $218,218,281$, and $156 \mathrm{C}$, respectively. Application of the Bjerrum theory showed that, somewhat above each of these temperatures, these electrolytes begin to associate by ion-pair formation. $\mathrm{H}_{3} \mathrm{PO}_{4}$ solutions associate at room temperature and above. $\mathrm{AgNO}_{3}$ solutions appear to associate at all temperatures, but no conclusions can be drawn because of complications cansed by hydrolysis. The equivalent conductances' at infinite dilution and the dissociation constants for each of the aforementioned electrolytes were calculated over their measured temperature ranges by the Shedlovsky method. The dissociation constants decrease with increasing temperature.

B. An apparatus was constructed and measurements were made on the conductances of $\mathrm{LiOH}$ and $\mathrm{NH}_{4} \mathrm{OH}$ solutions over the temperature range of $100 \mathrm{~F}(38 \mathrm{C})$ to $520 \mathrm{~F}(271 \mathrm{C})$. The equivalent conductances at infinite dilution and the dissociation constants were calculated for these solutions by the Shedlovsky method. Application of the Bjerrum theory indicated $\mathrm{LiOH}$ that some attractive force, in addition to ion-ion attraction, was acting ketween the $\mathrm{Li}^{+}$and $\mathrm{OH}^{-}$ions.

C. The $\mathrm{pH}$ of reactor coolants using $\mathrm{LiOH}$ or $\mathrm{NH}_{4} \mathrm{OH}$ was calculated from the dissociation constants for water, $=\mathrm{iOH}$, and $\mathrm{NH}_{4} \mathrm{OH}$ at elevated temperatures. Reactor coolants containing $\mathrm{NH}_{4} \mathrm{OH}$ are only 0.5 of a $\mathrm{pH}$ unit more basic than water at reactor temperature whereas a reactor coolant containing $\mathrm{LiOH}$ is 1.5 to $2 \mathrm{pH}$ units more basic

\section{TABLE XI}

CHANGE IN THE pH OF WATER, $\mathrm{NH}_{4} \mathrm{OH}$, AND LiOH SOLUTIONS AS A FUNCTION OF TEMPERATURE

\begin{tabular}{ccc}
$\begin{array}{c}\text { Temperature } \\
\text { (F) }\end{array}$ & & Water \\
\cline { 1 - 1 } 77 & & 7.00 \\
212 & & 6.16 \\
313 & & 5.83 \\
424 & & 5.67 \\
583 & & 5.89
\end{tabular}

$\mathrm{pH}$

\begin{tabular}{lc}
$\mathrm{NH}_{4} \mathrm{OH}$ & Solutions \\
\hline 8.00 & $9 . \overline{\mathrm{s} 0}$ \\
6.41 & 7.77 \\
5.96 & 6.96 \\
5.71 & 6.41 \\
5.90 & 6.28
\end{tabular}

$\mathrm{pH}$ LiOH Solutions

$9.00 \quad 10.50$

$7.30 \quad 8.80$

$6.62 \quad 8.12$

$6.29 \quad 7.76$

$\begin{array}{ll}6.64 & 8.12\end{array}$ 


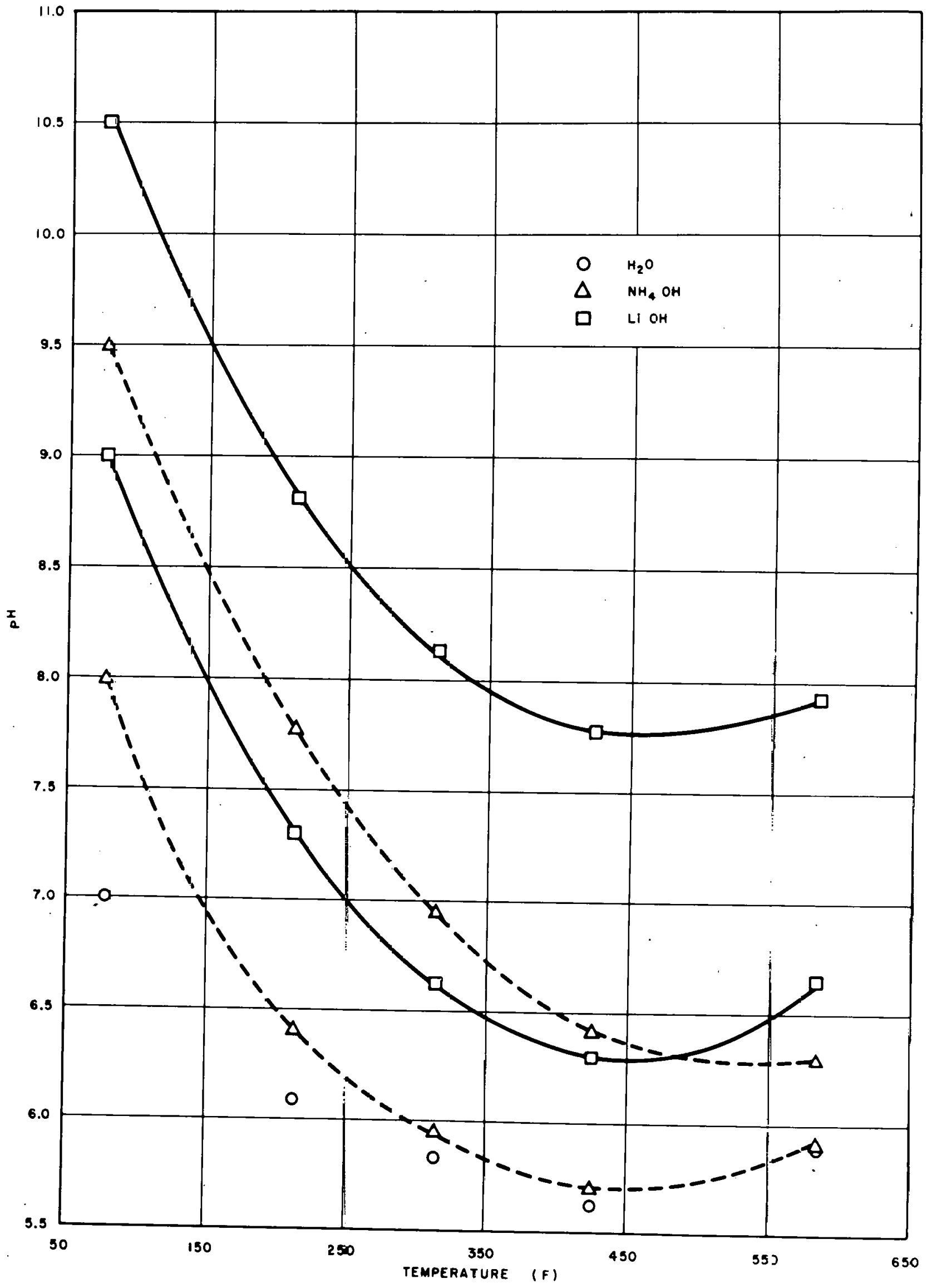

Figure 17. Variations of $\mathrm{pH}$ of Water, $\mathrm{LiOH}$, and $\mathrm{NH}_{4} \mathrm{OH}$ Solutions with Temperatu:e 
than water. The differences in concentrations of suspended corrosion products found in the different reactor coolants may well be explained by this difference in basicity.

APPENDIX I. DATA COMPILED BY NOYES ON VARIOUS ELECTROLYTES AT ELEVATED TEMPERATURES (TABLE I-1)

TABLE I-1

DATA COMPILED BY NOYES ON VARIOUS ELECTROLYTES AT ELEVATED TEMPERATURES

$\mathrm{C} \times 10^{3}$

Temperature (C) $\Omega \quad$ (equiv/liter)

A. $\mathrm{NaCl}$

TABLE I-1

DATA COMPILED BY NOYES ON VARIOUS ELECTROLYTES AT ELEVATED TEMPERATURES (Cont)

$\mathrm{C} \times 10^{3}$

\begin{tabular}{crrr} 
Temperature (C) & \multicolumn{1}{c}{$\Omega$} & (equiv/liter) \\
306 & & & \\
306 & 971 & & 0.346 \\
306 & 972 & & 1.330 \\
306 & 895 & & 6.930 \\
306 & 883 & 6.990 \\
306 & 691 & & 70.200 \\
306 & 694 & & 70.500
\end{tabular}

B. $\mathrm{KCl}$

18

18

18

18

100

100

100

140

140

156

156

218

218

218

281

281

281

281

306

306

306

306

306

306

$513.0 \quad 9.110$

$445.5 \quad 91.100$

$745 \quad 0.420 \quad$ C. $\mathrm{HCl}$

740

727

725

1.680

1. 690

689.5

690.0

$58 \overline{6} .0$

585.0

8. 43

8.44

84.40

86.60

0.373

1. 480

7. 470

7.530

75. 700

77.600

156

156

156

156
128. 11

126. 35

122.43

112.03

393.3

377.7

536.7 .

535

449

589

563

782.0

746.0

635.5

949

889

730

726

1051

1022

937

935

730

735

0.500

2.000

10.000

100.000

1.920

9.580

95.900

1.850

93.000

1. 824

9.100

1. 680

8. 440

84.400

1. 490

7.510

74. 300

75.600

0. 347

1. 380

6. 960

6. 990

70.200

70.500

375. 2

0.500

373.6

1.998

368.1

9.990

350.6

99.900

836

0. 479

827

1.998

808

9. 590

756

95.900

1065

0.456

1049

1. 820

1018

9. 110

91.100 
TABLE I-1

DATA COMIPILED BY NOYES ON VARIOUS ELECTROLYTES AT ELEVATED TIMPERATURES (Cont)

\begin{tabular}{|c|c|c|}
\hline Temperatuze (C) & $\Lambda$ & $\begin{array}{c}\mathrm{C} \times 0^{3} \\
\text { (equiv/liter) }\end{array}$ \\
\hline 218 & 1243 & 0.422 \\
\hline 218 & 1220 & 1.690 \\
\hline 218 & 1174 & 8.430 \\
\hline 218 & 1040 & 84.300 \\
\hline 260 & 1332 & 2.030 \\
\hline 260 & 1226 & 10.030 \\
\hline 306 & 1337 & 2.030 \\
\hline 306 & 1162 & 10.030 \\
\hline
\end{tabular}

D. $\mathrm{NaOH}$

$\begin{array}{rrr}18 & 212.1 & 2.038 \\ 18 & 211.8 & 4.033 \\ 18 & 205.5 & 21.520 \\ 18 & 200.6 & 50.2 \text { 현 } \\ & & \\ 100 & 582.1 & 1.947 \\ 100 & 576.9 & 3.851 \\ 100 & 560.6 & 18.360 \\ 100 & 542.7 & 47.050 \\ & & \\ 156 & 812.6 & 1.850 \\ 156 & 803.3 & 3.678 \\ 156 & 774.1 & 17.4 \leq 0 \\ 156 & 745.3 & 44.71 .0 \\ & & \\ 218 & 1008.8 & 3.464 \\ 218 & 941.7 & 16.140 \\ 218 & 891.6 & 41.38 .0\end{array}$

E. $\mathrm{AgNO}_{3}$

$\begin{array}{rrr}18 & 112.2 & 1.998 \\ 18 & 107.2 & 12.480 \\ 18 & 104.0 & 24.950 \\ 18 & 100.2 & 49.860 \\ 18 & 94.6 & 99.800 \\ & & \\ 100 & 351.0 & 1.916 \\ 100 & 335.0 & 11.979 \\ 100 & 321.5 & 23.950 \\ 100 & 308.0 & 47.83 . \\ 100 & 289.0 & 95.80) \\ & & \\ 156 & 532 & 1.821 \\ 156 & 504 & 11.37 \text { ) } \\ 156 & 481 & 22.75) \\ 156 & 457 & 45.430 \\ 156 & 426 & 91.20 . \\ & & \\ 218 & 720 & 1.685 \\ 218 & 672 & 10.520 \\ 21.3 & 635 & 21.07 \\ 21.3 & 597 & 42.130 \\ 213 & 548 & 84.600\end{array}$

TABLE I-1

DATA COMPILED BY NOYES JN VARIOUS ELECTROLYTES AT ELEVATED TEMPERATURES (Cont)

$\mathrm{C} \times 10^{3}$

\begin{tabular}{cccc} 
Temperature (C) & \multicolumn{1}{c}{$\Lambda$} & (equiv/liter) \\
281 & & \\
281 & 796 & & 1.500 \\
281 & 685 & & 9.380 \\
281 & 616 & & 75.700 \\
& & \\
306 & 937 & & 1.394 \\
306 & 830 & & 8.710 \\
306 & 693 & & 35.100 \\
306 & 617 & & 70.600
\end{tabular}

F. $\mathrm{H}_{3} \mathrm{PO}_{4}$

18

18

18

18

18

25

25

25

25

25

50

50

50

50

50

75

75

75

75

75

100

100

100

100

100

128

128

128

128

128

156

156

156

156

156
329.9

283.2

191.3

122.8

96.6

366.1

312.0

208.3

132.7

104.1

0.2263

1.9972

12.4825

49.5000

99.8600

491.1

401.4

255.1

158.5

123.2

0.2259

之. 9942

12. 4640

49.8750

99. 7110

0. 2239

1. 9765

1 . 3530

4 . 4320

98.824

597.7

465.9

0. 2209

1.9499

280.9

170.3

12.1870

48.7670

131.297 .4940

685.1

503.2

0.2172

288.2

1.9174

11.9840

$170.6 \quad 47.9530$

$130.6 \quad 95.8680$

758.5

0.2121

517.0

280.5

162.3

1. 8718

11.6986

46.8130

123.4

93. 5890

801.8

503.2

260.0

147.6

111.7
0.2064

1. 8215

11.3840

45.5560

91.0750 


\section{RE FERENCES}

1. Carnegie Institute of Washington, Publication \#63, Press of B.S. Adams, Washington, D.C.

2. L. Onsager, "The Theory of Electrolytes. I," Z. Physik 27, 388-92 (1926); L. Onsager, "The Theory of Electrolytes. II," Z. Physik 28, 27798 (1927); L. Onsager, "Report on a Revision of the Conductivity Theory," Trans. Faraday Soc 23, 341-9 (1927)

3. T. Shedlovsky, "An Equation for Electrolytic Conductance," J. Am. Chem. Soc. 54, 1405-11 (1932)

4. J. Wyman Jr., and E.N. Ingalls, "The Dielectric Constant of Deuterium Oxide," J. Am. Chem. Soc. $60,1182-84$ (1938)

5. G.C. Akerlof and H.I. Oshry,. "The Dielectric Constant of Water at High Temperatures and in Equilibrium with its Vapor," J. Am. Chem. Soc. 72, 2844-47 (1950)

6. N.E. Dorsey, Comp., "Properties of Ordinary Water-Substance," pp. 183-5, Reinhold Publishing Corporation, New York, 1940

7. H.S. Harned and B.B. Owen, "The Physical Chemistry of Electrolytic Solutions," 3rd ed., Chapter VI, Reinhold Publishing Corporation, New York, 1958

8. T. Shedlovsky, "Computation of Ionization Constants and Limiting Conductance Values from Conductivity Measurements,' J. Franklin Inst. $\underline{225,} 739-43$ (1938)

9. R.M. Fuoss and C.A. Kraus, "Properties of Electrolytic Solutions. II. The Evaluations of $\Lambda_{\mathrm{o}}$ and of $\mathrm{K}$ for Incompletely Dissociated Electrolytes," J. Am. Chem. Soc. 55, 476-88 (1933)
10. P. Debye and E. Huckel, "The Theory of Electrolytes. I. Lowering of Freezing Point and Related Phenomena," Z. Physik 24, 185-206 (1923)

P. Debye and E. Huckel, "Thesry of Electrolytes. II. The Limiting Law of Electrical Conductivity," Z. Physik 24, 3J5-25. (1923)

11. H.S. Harned and B.B. Owen, "Bjer=um's Theory of Ionic Association" in "The Physical Chemistry of Electrolytic Solutions," 3rd ed., pp. 70-74, Reinhold Publishing Corporation, New York, 1958

12. B.E. Conway, "Electrochemical Data," pp. 2930, Elsevier Publishing Company; New York, 1952

N.A. Lange and G.M. Forker, "Handbook of Chemistry," 6th ed., pp. 96-7, Handbook Publishers Inc., Sandusky, Ohio, 1946

13. L.S. Darken and H.F. Meier, "Conductances of Aqueous Solutions of the Hydroxides of Lithium, Sodium and Potassium at $25^{\circ}, " \therefore$. Am. Chem. Soc. 64, 621-3 (1942)

14. W.H. Zachariasen, "A Set of Empirical Crystal Radii For Ions with Inert-Gas Configuration," Z. Krist. 80, 137-53 (1931)

15. J. Johnston, "The Change of the Equivalent Conductance of Ions with the Temperature," J. Am. Chem. Soc. 31, 1010-19 (1909)

16. A.A. Noyes, Y. Kato, and R.B. Sosman, "The Hydrolysis of Ammonium Acetate and the Ionization of Water at High Temperatures," $\mathrm{J}$. Am. Chem. Soc. 32, 159-178 (1910)

17. R.M. Fuoss and F. Accascina, "Electrolytic Conductance," Interscience Publishers, Inc., New York, 1959 


\section{THIS PAGE \\ WAS INTENTIONALLY \\ LEFT BLANK}

